Review Article

\title{
Development of a Promising Fish Model (Oryzias melastigma) for Assessing Multiple Responses to Stresses in the Marine Environment
}

\author{
Sijun Dong, Mei Kang, Xinlong Wu, and Ting Ye \\ Key Lab of Urban Environment and Health, Institute of Urban Environment, Chinese Academy of Sciences, \\ Number 1799 Jimei Street, Xiamen 361021, China \\ Correspondence should be addressed to Sijun Dong; sjdong@iue.ac.cn
}

Received 5 November 2013; Revised 8 January 2014; Accepted 23 January 2014; Published 3 March 2014

Academic Editor: Zhi-Hua Li

Copyright (C) 2014 Sijun Dong et al. This is an open access article distributed under the Creative Commons Attribution License, which permits unrestricted use, distribution, and reproduction in any medium, provided the original work is properly cited.

\begin{abstract}
With the increasing number of contaminants in the marine environment, various experimental organisms have been "taken into labs" by investigators to find the most suitable environmentally relevant models for toxicity testing. The marine medaka, Oryzias melastigma, has a number of advantages that make it a prime candidate for these tests. Recently, many studies have been conducted on marine medaka, especially in terms of their physiological, biochemical, and molecular responses after exposure to contaminants and other environmental stressors. This review provides a literature survey highlighting the steady increase of ecotoxicological research on marine medaka, summarizes the advantages of using $O$. melastigma as a tool for toxicological research, and promotes the utilization of this organism in future studies.
\end{abstract}

\section{Introduction}

Estuaries and coastal waters are contaminated by high levels of anthropogenic pollutants [1], creating an urgent need for ecotoxicological studies of marine pollution. The ecotoxicological characteristics of pollutants in saltwater and freshwater environments are different. The parameters of seawater are significantly different from those of freshwater (i.e., salinity, density, buoyancy, $\mathrm{pH}$, ionic strength, and dissolved oxygen (DO)), and these differences impact the ecotoxicological characteristics of the pollutants, such as the packing fraction and size, the distribution of the contaminants in liquid and solid phases, and the bioaccumulation of the contaminants [2-4].

In addition, the studies of the organisms living in the two different environments have also presented different results. Although Oryzias latipes (freshwater fish) and Oryzias melastigma (seawater fish) are closely related, their branchial FXYD domain-containing ion transport regulator (FXYD) proteins exhibit divergent expression patterns [5]. Kif7 is not expressed in $O$. melastigma but is highly expressed in the brain of zebrafish, which is a freshwater fish [6]. There is an inverse correlation between the muscle water contents (MWC) and salinity in O. latipes; however, the two parameters are not related in O. melastigma [7]. Exposure to perfluorooctane sulfonates (PFOS) shortened the hatching time and increased the hatching rate of $O$. melastigma but had the opposite effects in zebrafish [8-10]. These differences illustrate that ecotoxicological results from freshwater environments cannot be directly applied to the marine environment. At present, aquatic toxicological research is largely carried out under freshwater environmental conditions, and research in the marine environment is urgently needed.

The biologic impact of toxic pollutants on fish is an important area of study in ecotoxicology. Fish models, such as zebrafish (Danio rerio), tilapia (Oreochromis niloticus), and rainbow trout (Oncorhynchus mykiss), have been widely used for ecotoxicological studies in the freshwater environment. Although some estuarine species, for example, Corophium acherusicum, Enteromorpha linza, and Ctenogobius giurinus, can be used for the study of ecotoxicology in marine environments, the research still lags well behind that in freshwater environments, and problems such as species specificity and the lack of genetic information in these species do exist. 
O. melastigma, also named O. dancena or Indian medaka, has many advantages as a fish model in marine toxicological research. This review summarizes the advantages and research findings of marine toxicological studies using $O$. melastigma and encourages further investigation of ecotoxicology in the marine environment using this fish model.

\section{Advantages of $O$. melastigma as a Research Model in Toxicological Studies}

O. melastigma originates from the coastal waters and fresh waters of Pakistan, India, Myanmar, and Thailand. In classification, O. melastigma and O. latipes belong to the order Beloniformes, family Adrianichthyidae and genera Oryzias. The embryo of this species has been identified as an important tool for toxicology investigations by the regime of ILSI Health and Environmental Sciences Institute (HESI). As a fish model, it shares many advantages as follows.

(1) O. melastigma is small in size (4.5 to $23 \mathrm{~mm}$ ) and has a short generation time (2-3 months). These characteristics make it available to culture on a large scale under laboratory conditions (30\%o artificial seawater, $28 \pm 1^{\circ} \mathrm{C}$, and in a $14 \mathrm{~h}$ light: $10 \mathrm{~h}$ dark cycle). The relatively large eggs and transparent color simplify experimental observations and operations, such as observing developmental changes during each stage of growth [11].

(2) O. melastigma has distinct sexual dimorphism, and the morphology of the anal fin is very prominent approximately 1 month after hatching, rendering it highly desirable for gender studies [12]. Researchers have recommended that future risk evaluation of immune-modulatory chemicals must include parallel assessment of both genders. This makes O. melastigma, owing to its characteristics of distinct gender dimorphism and the presence of sex-determining Dmy gene of its homologous species O. latipes, suitable for toxicity evaluation [13].

(3) O. melastigma possesses strong environmental tolerance. This organism is capable of adapting to a wide range of temperatures; thus, mutants can be derived that are conveniently temperature sensitive [14]. $O$. melastigma has the ability to survive in aquatic environments with a wide range of salinity. Although $O$. latipes can adapt to varying salinity environments to some degree, the adaptive capacity of $O$. latipes is lower than that of O. melastigma, which can thrive in water of varying salinity ranging from 0 to $35 \mathrm{ppt}$ [1].

(4) The eggs and larvae of O. melastigma are sensitive to many environmental pollutants. If the specific sensitive gene responding to pollutants or other environmental stresses can be identified at the molecular level, then environmental pollution can be quickly identified. The molecular staging of O. melastigma embryos, focusing on the heart, pectoral fin, brain, eye, pancreas, muscle, liver, and neuron system, has been fully described [15].
(5) Studies of O. latipes in anatomy, physiology, and other aspects have been increasingly extensive and systematic, and the genome sequences of $O$. latipes have been completed. Many common characteristics exist between $O$. latipes and O. melastigma in phylogeny; thus, the brackish $O$. melastigma can serve as a good marine fish model for developmental studies by utilizing the resources developed from $O$. latipes. The corresponding genetic chip information of O. melastigma has been acquired which makes it convenient for the study of $O$. melastigma $[1,14,16]$. Additionally, homologous species could be fully used for comparative biology, in a similar manner to Drosophila, for which the genome analysis of multiple species has greatly promoted the study of comparative biology $[14,17]$.

All of these advantages enhance the potential of $O$. melastigma to be a competent model organism in marine ecotoxicology.

\section{The Research Background of O. melastigma in Molecular Biology}

Sharing a high degree of similarity, most of the research findings of the congeneric species of O. melastigma, such as O. latipes, could be applied to O. melastigma mostly. Notably, even though $O$. melastigma is similar to the other medaka species, some differences still exist. For example, omChgh is characterized by eight exons and seven introns, while the second isoform of the Chgh gene has only seven exons in the O. latipes genome $[6,18,19]$. Dlx2 is expressed only in the telencephalon and diencephalon of $O$. melastigma, while it is also expressed in the rhombencephalon of $O$. latipes [1]. $O$. latipes and O. melastigma share completely identical peptide sequences but bear very different glycan structures [19]. This phenomenon suggests that further exploration of the marine medaka genome and proteome is needed [20].

3.1. The Research Background of O. melastigma Genes. A substantial number of molecular biological studies for $O$. melastigma are being conducted. The complete mitochondrial genome of $O$. melastigma has been obtained from the genome data sequenced by next-generation sequencers [21]. A batch of organ-specific molecular markers have also been identified, such as the makers for brain, eyes, heart, liver, and muscle [15]. These markers can be used to indicate the developmental status of specific organs, and their abnormal expression can be used to indicate the toxicity of pollutants on organ development. Chen et al. [1] analyzed the expression of 11 organ-specific expression genes during each period of embryonic development by in situ hybridization (ISH) and determined that 8 of the 11 genes are similar to those expressed during the embryonic development of zebrafish and O. latipes.

In addition to the above specified genes of organ development, some functional genes in different tissues have been analyzed as well (Table 1). Some immune-related genes, 
TABLE 1: Expression of the cloned genes of O. melastigma in different tissues under various environmental stresses.

\begin{tabular}{|c|c|c|c|c|}
\hline Functions & Genes & Exposed tissues & Exposed to & References \\
\hline Reference genes & 18S, Rpl7, and $\beta$-actin & & & \\
\hline \multirow{5}{*}{ Hypoxia-responsive } & Telomerase reverse transcriptase (Tert) & $\begin{array}{l}\text { Ovary, liver, testis, kidney, } \\
\text { gill, brain, spleen, intestine, } \\
\text { eye, muscle, and skin }\end{array}$ & Hypoxia & {$[16,22]$} \\
\hline & 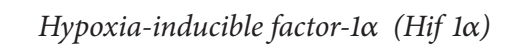 & Liver, testis & Hypoxia & {$[22]$} \\
\hline & Erythropoietin (Epo) & Liver, testis, and embryos & Hypoxia, PFOS & {$[22,23]$} \\
\hline & Leptin receptor (Lepr) & $\begin{array}{l}\text { Liver, gill, heart, kidney, } \\
\text { gill, brain, spleen, intestine, } \\
\text { eye, muscle, ovary, and } \\
\text { testis }\end{array}$ & Hypoxia & {$[24]$} \\
\hline & Hemoxygenase-1 $(\mathrm{Ho})$ & Liver, gill, and heart & WAFs, Hypoxia & {$[24,25]$} \\
\hline \multirow{5}{*}{ Immune toxicity } & Glutathione peroxidase (Gpx) & Embryos & PFOS & {$[26]$} \\
\hline & Catalase (Cat) & Embryos & PFOS & {$[26]$} \\
\hline & Uncoupling protein 2 (Ucp2) & Embryos & PFOS & {$[26,27]$} \\
\hline & Cyclooxygenase-2 (Cox2) & Embryos & PFOS & {$[26]$} \\
\hline & 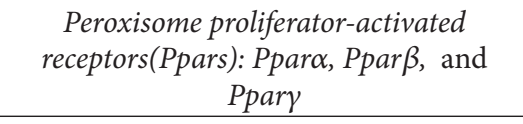 & Embryos, whole fish & PFOS, WAFs & {$[25,26,28]$} \\
\hline \multirow{7}{*}{$\begin{array}{l}\text { Complement-related } \\
\text { genes }\end{array}$} & Lectin, mannose-binding 2 (Mbl2) & Liver & PBDE-47 & {$[29]$} \\
\hline & Cyan fluorescent protein (Cfp) & Liver & PBDE-47 & {$[29]$} \\
\hline & $\begin{array}{l}\text { Complement component: C1r/s, C3, C9, } \\
\text { C3-2, C4, C1q, C5, C8, C1 inhibitor }\end{array}$ & Liver & $\begin{array}{l}\text { PBDE-47, Vibrio } \\
\text { parahaemolyticus }\end{array}$ & {$[29,30]$} \\
\hline & Prothrombin (F2) & Liver & & {$[30]$} \\
\hline & Complement factor: $\mathrm{Hf}, \mathrm{Bf}$ & Liver & $\begin{array}{c}\text { Vibrio } \\
\text { parahaemolyticus }\end{array}$ & {$[30]$} \\
\hline & Hepcidin (Нер): Hep1, Нер2 & $\begin{array}{l}\text { Liver, spleen, gill, intestine, } \\
\text { ovary, testis, brain, and } \\
\text { embryos }\end{array}$ & $\begin{array}{c}\text { Vibrio } \\
\text { parahaemolyticus }\end{array}$ & {$[30]$} \\
\hline & $\begin{array}{c}\text { Mannose-binding lectin-associated serine } \\
\text { protease (Masp) }\end{array}$ & Liver & $\begin{array}{c}\text { Vibrio } \\
\text { parahaemolyticus }\end{array}$ & {$[30]$} \\
\hline \multirow{4}{*}{$\begin{array}{l}\text { Inflammation-related } \\
\text { genes }\end{array}$} & Tumor necrosis factor- $\alpha(\operatorname{Tn} f \alpha)$ & Embryos & PFOS, BPA & {$[26,31]$} \\
\hline & Interleukin (Il): Ill $\beta$, Il8 & Embryos & PFOS, BPA & {$[26,31]$} \\
\hline & CC chemokine eotaxin-1 (Ccl11) & Embryos & BPA & {$[31]$} \\
\hline & Superoxide dismutase (Sod) & Embryos & PFOS, BPA & {$[26,31]$} \\
\hline \multirow{3}{*}{$\begin{array}{l}\text { Osmoregulatory } \\
\text { mechanism }\end{array}$} & $\mathrm{Na}^{+} / \mathrm{K}^{+}$-ATPase (Nka) & Gill, embryos & $\begin{array}{l}\text { BPA, SW (35\%o), BW } \\
(15 \% \text { o }) \text { and FW (0) }\end{array}$ & {$[7,31,32]$} \\
\hline & $\begin{array}{c}\mathrm{Na}^{+}, \mathrm{K}^{+}, 2 \mathrm{Cl}^{-} \text {cotransporter }(N k c c): \\
N k c c l a, N k c c 1 b, \text { and } N k c c 2\end{array}$ & $\begin{array}{l}\text { Gill, liver, testis, intestine, } \\
\text { ovary, brain, muscle, } \\
\text { kidney, heart, Fin, and eye }\end{array}$ & $\begin{array}{l}\text { SW (35\%o), BW } \\
(15 \%) \text {, and FW (0) }\end{array}$ & {$[32]$} \\
\hline & $\begin{array}{l}\text { FXYD domain-containing ion transport } \\
\text { regulator (Fxyd): Fxyd5, Fxyd6, Fxyd7, } \\
\text { Fxyd8, Fxyd9, Fxyd11, and Fxyd12 }\end{array}$ & $\begin{array}{c}\text { Gill, intestine, kidney, } \\
\text { brain, eye, liver, and caudal } \\
\text { fin }\end{array}$ & $\begin{array}{l}\text { SW (35\%o), BW } \\
(15 \% 0), \text { FW (0) }\end{array}$ & {$[5]$} \\
\hline \multirow{8}{*}{$\begin{array}{l}\text { Cardiac } \\
\text { development-related } \\
\text { genes }\end{array}$} & $\begin{array}{c}\text { NK2 transcription factor related } 5 \\
(N k \times 2.5)\end{array}$ & Embryos & PFOS, BPA & {$[23,31]$} \\
\hline & Cyclooxygenase (Cox): Cox1, Cox2 & Embryos & PFOS, BPA & {$[23,31]$} \\
\hline & ATP synthase & Embryos & PFOS & {$[23,27]$} \\
\hline & Bone morphogenetic protein (Bmp4) & Embryos & PFOS, BPA & {$[23,31]$} \\
\hline & Fibroblast growth factor 8 (Fgf8) & Embryos & PFOS, BPA & {$[23,31]$} \\
\hline & GATA-binding protein 4 (Gata4) & Embryos & PFOS, BPA & {$[23,31]$} \\
\hline & Leptin receptor (Lerp) & Embryos & BPA & {$[31]$} \\
\hline & $\begin{array}{l}\text { SET and MYND domain containing } 1 \\
\text { (Smyd1) }\end{array}$ & Embryos & PFOS & {$[23]$} \\
\hline
\end{tabular}


TABle 1: Continued.

\begin{tabular}{|c|c|c|c|c|}
\hline Functions & Genes & Exposed tissues & Exposed to & References \\
\hline \multirow{17}{*}{ Metabolisms } & Cytochrome P450 (Cyps) & $\begin{array}{l}\text { Liver, gill, embryos, } \\
\text { intestine, and ovary }\end{array}$ & PFOS, WAFs & {$[25,28,33]$} \\
\hline & Aldehyde dehydrogenase (Aldh) & & WAFs & {$[25]$} \\
\hline & $\begin{array}{c}\text { Glutathione S-transferase (Gst): Gsta, } \\
\text { Gstk, Gsto, Gstt, and Gstz }\end{array}$ & & WAFs & {$[25]$} \\
\hline & $\begin{array}{c}\text { Sulfotransferase (Sult): Sult1, Sult2 } \\
\text { cytosolic, Sult2b1, Sult2b2, Sult3 cytosolic, } \\
\text { Sult3-like, Sult4a1, and Sult6b1 }\end{array}$ & & WAFs & {$[25]$} \\
\hline & $\begin{array}{c}\text { UDP-glucuronyltransferases (Ugts): Ugt1b, } \\
\text { Ugt2a, Ugt2a2, Ugt2a3, Ugt2b33, } \\
\text { Ugt2b3-like, Ugt5a1, and Ugt5g1 }\end{array}$ & & WAFs & {$[25]$} \\
\hline & $\begin{array}{c}\text { Hydroxysteroid dehydrogenase }(H s d) \text { : } \\
3 \beta-H s d, 11 \beta-H s d \text {, and } 17 \beta-H s d\end{array}$ & & WAFs & {$[25]$} \\
\hline & $\begin{array}{c}\text { Aryl Hydrocarbon Receptor (Ahr): Ahrl, } \\
\text { Ahr2 }\end{array}$ & Embryos, whole fish & PFOS, WAFs & {$[25,28]$} \\
\hline & $5 \alpha$-reductase $(S r d 5 a)$ & & WAFs & {$[25]$} \\
\hline & $\begin{array}{c}\text { Steroidogenic acute regulatory protein } \\
\text { (Star) }\end{array}$ & & WAFs & {$[25]$} \\
\hline & $\begin{array}{c}A T P \text {-binding cassette }(A b c): A b c b 1, A b c c 2, \\
A b c c 3, A b c c 4, \text { and } A b c g 2\end{array}$ & & WAFs & {$[25]$} \\
\hline & $\begin{array}{c}\text { Heat shock protein (Hsp): Hsp10, Hsp22, } \\
\text { Hsp27, Hsp30, Hsp60, Hsp70, Hsp75, } \\
\text { Hsp90a, Hsp90 } \beta, H s p \beta 7, \text { and Hsp } \beta 11\end{array}$ & & WAFs & {$[25]$} \\
\hline & Choriogenin $\mathrm{H}$ and L (Chgh and Chgl) & Liver, embryos, and larvae & $\begin{array}{l}\text { PFOS, E2, EE2, BPA, } \\
\text { and NP }\end{array}$ & {$[28,34]$} \\
\hline & Kinesin superfamily7 (Kif7) & $\begin{array}{c}\text { Brain, kidney, liver, muscle, } \\
\text { ovary, and testicle }\end{array}$ & & {$[6]$} \\
\hline & $\begin{array}{c}\text { Aryl hydrocarbon receptor nuclear } \\
\text { translocator (Arnt) }\end{array}$ & Embryos & PFOS & {$[28]$} \\
\hline & Vitellogenin (Vtg) & $\begin{array}{l}\text { Embryos, liver, gill, } \\
\text { intestine }\end{array}$ & PFOS & {$[28]$} \\
\hline & Estrogen receptor $(\mathrm{Er})$ & Embryos & PFOS & {$[28]$} \\
\hline & Horiolysin H and L (Hce and Lce) & Embryos & PFOS & {$[10]$} \\
\hline
\end{tabular}

Notes: $2,2^{\prime}, 4,4^{\prime}$-tetrabromodiphenyl ether (PBDE-47), bisphenol A (BPA), polycyclic aromatic hydrocarbons (PAHs), sea water (SW), fresh water (FW), brackish water (BW), 17 $\beta$-Estradiol (E2), 17 $\alpha$-ethinylestradiol (EE2), 4-nonylphenol (NP).

including complement-related genes and inflammationrelated genes, have been analyzed. Bo et al. used suppression subtractive hybridization ( $\mathrm{SSH}$ ) to identify differentially expressed immune genes in the liver of O. melastigma infected with Vibrio parahaemolyticus [30]. Based on an NCBI BLAST search of the 1279 sequenced clones in the SSH libraries, 396 genes were identified, and 38 were involved in the immune process. Additionally, genes involved in cellular metabolism, biological regulations, general response to stimuli, transport processes, signal transduction, and cellular component organization were obtained [30]. Some genes related to metabolism, osmoregulatory and cardiac development in O. melastigma have also been submitted. Whole om Cyp genes were registered at the GenBank database. To date, various Cyp gene families have been identified. The transcript profiling of whole omCyp genes has been finished for O. melastigma exposed to water accommodated fractions (WAFs) of Iranian crude oil [25, 33].
Second generation high-throughput sequencing technology has greatly enhanced the ability to obtain genetic information. Huang et al. extracted RNA from O. melastigma following exposure to pollutants during various developmental periods and used Illumina high-throughput sequencing to obtain $6 \mathrm{~GB}$ data. They performed bioinformatics analyses and identified a large number of toxicology-related genes, thus providing a broad molecular basis for further toxicological investigations [27].

Differentially expressed genes can be largely obtained in fish after exposure to pollutants using gene chip technology. Chinese scholars have constructed a dedicated gene chip for O. melastigma, which contains 180 genes related to cell division, detoxification reactions, hypoxia response, oxidative stress, apoptosis, growth, sex determination, gonadal differentiation, and reproductive hormone secretion [35]. This chip includes the most common marker genes for toxicological studies and can be used effectively for gene screening with 
differential expression. Using newly developed sequencing technology (Illumina RNA-Seq) and digital gene expression (DGE) technology, a total of approximately 145 thousand unigenes were obtained with 565 bp of unigene N50 [27], which were further enriched in various molecular pathways involved in the response to PFOS exposure and related to neurobehavioral defects, mitochondrial dysfunction, and the metabolism of proteins and fats.

3.2. The Research Foundation of O. melastigma Proteins. The detection of protein expression levels requires corresponding antibodies. Because of the conservation of homologous proteins, antibodies have certain commonalities in allied species. The antibody library of zebrafish has been relatively completed; thus we can use them to directly screen for the specific antibody that reacts with the homologous protein in $O$. melastigma, avoiding the tedious processes of antibody preparation. Through immunohistochemical assay (IHCA) screening of whole embryos, 17 types of zebrafish antibodies can cause specific immune reactions with $O$. melastigma. These antibodies have a close relationship with the development of nerve, heart, and brain, providing a basis for toxicological research on protein levels $[15,16]$. In addition, mouse anti-human TERT monoclonal antibody mAb476 can specifically combine with the TERT protein of O. melastigma [16].

The tissue distribution of the protein expression in $O$. melastigma under various environment stresses has been partly finished intuitively by WB, IHCA, and matrix-assisted laser desorption/ionization tandem time-of-flight mass spectrometry (MALDI-TOF/TOF MS) (Table 2). The expression of the TERT protein in the cytoplasm and nucleus of $O$. melastigma can be quantified by Western blotting (WB) [41]. Kong et al. observed the TERT protein expression of $O$. melastigma in the testis, ovary, muscle, brain, gill, intestine, kidney, and liver of adult fish using IHCA [16]. Proliferating Cell Nuclear Antigen (PCNA) is the protein marker reflecting cell proliferation, which can be detected by means of IHCA in O. melastigma. Experimental results showed a significant correlation between PCNA and TERT in transcriptional and translational expression levels [11]. PCNA detection can also reflect the spatial and temporal characteristics of $O$. melastigma embryonic development [15].

Proteomics refers to the research method of identifying protein characteristics on the large-scale level, and it has become one of the hot spots of aquatic toxicology [39]. Quantitative proteomic analysis demonstrated that hepatotoxicity caused by $\mathrm{Hg}$ might involve oxidative stress, cytoskeleton impairment, and energy metabolism alteration, highlighting that the fish liver might be an important target for Hg attack. And proteins such as cathepsin D, GST, and peroxiredoxin1 responding to $\mathrm{Hg}$ treatment in a dose-dependent manner could be used as potential biomarkers of aquatic $\mathrm{Hg}$ monitoring [38]. Exposure to PbTx-1 resulted in the alteration of the protein expression involved in cell structure, macromolecule metabolism, neurotransmitter release, and the distribution of signal transduction which may help explain the damage mechanisms of aquatic toxins in fish [36].

\section{Utilization of $O$. melastigma in Toxicological Studies}

O. melastigma has been used as a research model for assessing multiple responses to stresses of organic chemicals, inorganic chemicals, detrimental organisms, and environmental stress (Table 3). The toxicity responses of $O$. melastigma are different from some species under environmental stresses, which may even have a totally opposite effect (Table 4).

4.1. Toxicological Studies for Organic Chemicals. The choriogenin of teleost fish is considered to be part of the structural interlayer of chorionic precursor cells, which are sensitive to estrogenic contaminants. It increased the expression of the egg-shell precursor protein gene in the liver when exposed to a high concentration of $17 \beta$-Glycol and $17 \alpha$-ethinyl estradiol [34]. The Chgh and Chgl of O. melastigma are sensitive to exposure to estradiol and nonylphenol, and the response of the male fish is more sensitive compared to the female. This indicates that the two genes can be used as sensitive biomarkers to detect pollution levels of estrogen contaminants in the marine environment [34].

The WAF exposure induced CYP-involved detoxification effects but reduced CYP-involved steroidogenic metabolism in the marine medaka. As well-characterized biomarkers of toxicants exposures, om Cypla and om Cyplb were highly induced following WAF exposure [25, 43]. Some previous studies have shown potentially synergistic effects after coexposure of O. melastigma embryos to CYP1A inhibitors and PAH-type CYP1A inducers [43]. The acute aquatic toxicity of some seawater organisms exposed to polycyclic aromatic hydrocarbons (PAHs) in the laboratory is summarized in Table 5. Distinctly, O. melastigma showed high tolerance to PAHs compared to other species. The heart elongation (heart tube) of O. melastigma embryos and heart deformities of these juvenile fishes have been recommended as potential biomarkers of the existence of $\mathrm{PAH}$ pollution by $\mathrm{Mu}$ et al. [43].

Studies quantified the endogenous expression of all six complement system genes including $\mathrm{Clr} / \mathrm{s}, \mathrm{Mbl2}, \mathrm{CfpF} 2, \mathrm{C} 3$, and $C 9$, in the liver of marine medaka and found that the expression levels were higher in males than in females. BDE47 exposure downregulates the expression of all six genes in males, while in females the expression of $M b l 2, C f p$, and F2 mRNAs was upregulated and C3 and C9 remained stable with exposure time and dose. These results indicate that the future direction for fish immunotoxicology should include parallel assessment for both genders [29]. Two hepcidins in $O$. melastigma play a complementary role in the innate defense system. Gender specificity should be taken into consideration in immunotoxicological studies in time and extent of induction of the two hepcidin genes in infected $O$. melastigma [48].

PFOS has estrogenic activity and endocrine-disruptive properties that elicit transcriptional responses on POPsrelated pathways in a stage-specific manner [61-63]. The marine biological toxicity of PFOS was systematically studied by Dong et al. using O. melastigma [10, 23, 26-28]. Their 
TABLE 2: Expression of proteins in different tissues of O. melastigma under various environmental stresses.

\begin{tabular}{|c|c|c|c|}
\hline Related functions & Proteins & $\begin{array}{c}\text { Expression tissues and exposure } \\
\text { condition }\end{array}$ & References \\
\hline \multirow{3}{*}{ Cell structure } & Histone-binding protein RBBP4 & Gill (Br) & {$[36]$} \\
\hline & Gelsolin & Gill, brain (Br) & {$[36]$} \\
\hline & Krt4 protein & Gill (Br) & {$[36]$} \\
\hline \multirow{35}{*}{ Oxidative stress response } & Hemoglobin beta chain & Gill (Br) & {$[36]$} \\
\hline & Histone $\mathrm{H} 3$ & Gill (Br) & {$[36]$} \\
\hline & Glial fibrillary acidic protein & Brain $(\mathrm{Br})$ & {$[36]$} \\
\hline & Keratin 15 [KRT15] & Brain $(\mathrm{Br})$, liver $(\mathrm{Hg})$ & {$[36,37]$} \\
\hline & Zgc: 65851 & Brain (Br) & {$[36]$} \\
\hline & Type I cytokeratin, enveloping layer [CYT1] & Brain $(\mathrm{Br})$, liver $(\mathrm{Hg})$ & {$[36,37]$} \\
\hline & Myosin light chain 2 & Brain $(\mathrm{Br})$ & {$[36]$} \\
\hline & Tropomyosin alpha-3 chain & Brain $(\mathrm{Br})$ & {$[36]$} \\
\hline & $\alpha$-Tubulin 1 & Liver $(\mathrm{Hg})$ & {$[37]$} \\
\hline & Keratin 8 & Liver $(\mathrm{Hg})$ & {$[37]$} \\
\hline & $\alpha$-Actin & Liver $(\mathrm{Hg})$ & {$[37]$} \\
\hline & Keratin 18 & Liver, brain $(\mathrm{Hg})$ & {$[37]$} \\
\hline & $\beta$-Actin & Liver, brain $(\mathrm{Hg})$ & {$[37]$} \\
\hline & Type I keratin-like protein & Liver $(\mathrm{Hg})$ & {$[37]$} \\
\hline & Lamin type B & Liver $(\mathrm{Hg})$ & {$[37]$} \\
\hline & Krt5 protein & Brain $(\mathrm{Hg})$ & {$[37]$} \\
\hline & Type II basic cytokeratin & Brain $(\mathrm{Hg})$ & {$[37]$} \\
\hline & Keratin K10 [KRT10] & Liver $(\mathrm{Hg})$ & {$[38]$} \\
\hline & Novel protein similar to vertebrate plectin 1 [PLEC] & Liver $(\mathrm{Hg})$ & {$[38]$} \\
\hline & Peroxiredoxin 4 & Liver $(\mathrm{Hg})$ & {$[38]$} \\
\hline & Peroxiredoxin 6 & Liver $(\mathrm{Hg})$ & {$[38]$} \\
\hline & Glutathione S-transferase [GSTR] & Liver $(\mathrm{Hg})$ & {$[38]$} \\
\hline & $\mathrm{SOD}[\mathrm{Cu}-\mathrm{Zn}]$ & Liver $(\mathrm{Hg})$ & {$[38]$} \\
\hline & Aldehyde dehydrogenase 1 family, member A2 & Brain $(\mathrm{Hg})$ & {$[38]$} \\
\hline & Aldehyde dehydrogenase, mitochondrial & Brain $(\mathrm{Hg})$ & {$[38]$} \\
\hline & Peroxiredoxin-2 [PRDX2] & Liver $(\mathrm{Hg})$ & {$[38]$} \\
\hline & Natural killer enhancing factor & Liver $(\mathrm{Hg})$ & {$[37]$} \\
\hline & Peroxiredoxin-1 [PRDX1] & Liver $(\mathrm{Hg})$ & {$[38]$} \\
\hline & DJ-1 protein [DJ-1] & Liver $(\mathrm{Hg})$ & {$[38]$} \\
\hline & Cathepsin D [CTSD] & Liver $(\mathrm{Hg})$ & {$[38]$} \\
\hline & proliferating cell nuclear antigen [PCNA] & $\begin{array}{l}\text { Testis, muscle, kidney, liver Cheek, } \\
\text { brain, intestine, and ovary embryo } \\
\text { during each development period }(\mathrm{H})\end{array}$ & {$[16,39]$} \\
\hline & Telomerase Reverse Transcriptase [TERT] & $\begin{array}{l}\text { Testis, brain, muscle, gill, intestine, } \\
\text { kidney }(\mathrm{N}) \text {, and liver }(\mathrm{H})\end{array}$ & {$[16]$} \\
\hline & superoxide dismutase [SOD] & Whole fish (Z) & {$[40]$} \\
\hline & Metallothionein [MT] & Whole fish (Z) & {$[40]$} \\
\hline & heat shock protein 70 [HSP70] & Whole fish (Z) & {$[40]$} \\
\hline
\end{tabular}


TABle 2: Continued.

\begin{tabular}{|c|c|c|c|}
\hline Related functions & Proteins & $\begin{array}{l}\text { Expression tissues and exposure } \\
\text { condition }\end{array}$ & References \\
\hline & ApoA-IV4 & Gill (Br) & {$[36]$} \\
\hline & Aldose reductase & Gill, brain $(\mathrm{Br})$ & {$[36]$} \\
\hline & Pyruvate carboxylase & Brain (Br) & {$[36]$} \\
\hline & Dpysl5a protein & Brain $(\mathrm{Br})$ & {$[36]$} \\
\hline & Triosephosphate isomerase & Brain $(\mathrm{Br})$ & {$[36]$} \\
\hline & Enolase & Brain (Br) & {$[36]$} \\
\hline & Glutamine synthetase & $\operatorname{Brain}(\mathrm{Br}, \mathrm{Hg})$ & {$[36,37]$} \\
\hline & Isovaleryl coenzyme A dehydrogenase & Brain $(\mathrm{Br})$ & {$[36]$} \\
\hline & Glyceraldehyde 3-phosphate dehydrogenase & Brain $(\mathrm{Br})$ & {$[36]$} \\
\hline & Homogentisate 1,2-dioxygenase & Liver $(\mathrm{Hg})$ & {$[37]$} \\
\hline & Alanyl-tRNA synthetase, cytoplasmic & Liver $(\mathrm{Hg})$ & {$[37]$} \\
\hline & Dihydrolipoamide S-acetyltransferase & Liver $(\mathrm{Hg})$ & {$[37]$} \\
\hline & Adenosylhomocysteinase & Liver $(\mathrm{Hg})$ & {$[37]$} \\
\hline & $\begin{array}{l}\text { Pyruvate dehydrogenase E1 component subunit } \\
\text { alpha, somatic form, mitochondrial }\end{array}$ & Liver (Hg) & {$[37]$} \\
\hline & Brain-type fatty acid binding protein & Liver $(\mathrm{Hg})$ & {$[37]$} \\
\hline & Methionine adenosyltransferase-like & Liver $(\mathrm{Hg})$ & {$[37]$} \\
\hline \multirow[t]{22}{*}{ Metabolism } & S-formylglutathione hydrolase & Liver $(\mathrm{Hg})$ & {$[37]$} \\
\hline & Apolipoprotein A1 & Brain $(\mathrm{Hg})$ & {$[37]$} \\
\hline & Pyruvate kinase & Brain $(\mathrm{Hg})$ & {$[37]$} \\
\hline & Dihydropyrimidinase-related protein 5 & Brain $(\mathrm{Hg})$ & {$[37]$} \\
\hline & Dihydropyrimidinase-like 2 & Brain $(\mathrm{Hg})$ & {$[37]$} \\
\hline & Enolase 1, (alpha) & Brain $(\mathrm{Hg})$ & {$[37]$} \\
\hline & Creatine kinase, brain $b$ & Brain $(\mathrm{Hg})$ & {$[37]$} \\
\hline & Total glutathione $[\mathrm{GSH}]$ & Whole fish (W) & {$[25]$} \\
\hline & Glutathione $S$-transferase [GST] & Whole fish (W) & {$[25]$} \\
\hline & Sulfotransferase [SULT] & Whole fish (W) & {$[25]$} \\
\hline & Superoxide dismutase [SOD] & Whole fish (W) & {$[25]$} \\
\hline & Glutathione reductase [GR] & Whole fish (W) & {$[25]$} \\
\hline & Glutathione peroxidase [GPx] & Whole fish (W) & {$[25]$} \\
\hline & Catalase, CAT & Whole fish (W) & {$[25]$} \\
\hline & ATP synthase subunit d, mitochondrial [ATP5H] & Liver (Hg) & {$[38]$} \\
\hline & $\begin{array}{l}\text { Electron-transferring-flavoprotein dehydrogenase } \\
\text { [ETFDH] }\end{array}$ & Liver $(\mathrm{Hg})$ & {$[38]$} \\
\hline & $\begin{array}{l}\text { Electron transferring flavoprotein subunit alpha, } \\
\text { mitochondrial [ETFA] }\end{array}$ & Liver (Hg) & {$[38]$} \\
\hline & Pyruvate dehydrogenase (lipoamide) beta [PDHB] & Liver $(\mathrm{Hg})$ & {$[38]$} \\
\hline & $\begin{array}{l}\text { Phytanoyl-CoA dioxygenase domain-containing } \\
\text { protein } 1 \text { [PHYD1] }\end{array}$ & Liver $(\mathrm{Hg})$ & [38] \\
\hline & $\begin{array}{l}\text { Delta3,5-delta2,4-dienoyl-CoA isomerase, } \\
\text { mitochondrial [ECH1] }\end{array}$ & Liver $(\mathrm{Hg})$ & [38] \\
\hline & Phosphorylase [PYGB] & Liver (Hg) & [38] \\
\hline & Formimidoyltransferase-cyclodeaminase [FTCD] & Liver $(\mathrm{Hg})$ & {$[38]$} \\
\hline
\end{tabular}


TABLe 2: Continued.

\begin{tabular}{|c|c|c|c|}
\hline Related functions & Proteins & $\begin{array}{l}\text { Expression tissues and exposure } \\
\text { condition }\end{array}$ & References \\
\hline \multirow{6}{*}{ Signal transduction } & Putative transient receptor protein 2 & Gill (Br) & {$[36]$} \\
\hline & Myosin regulatory light chain 2 & Gill (Br) & {$[36]$} \\
\hline & FXYD domain-containing ion transport regulator & Gill (S) & {$[5]$} \\
\hline & NKCCla-like protein & Gill (S) & {$[32]$} \\
\hline & NKA $\alpha$-subunit & Gill (S) & {$[7,32]$} \\
\hline & Grancalcin & Gill (Br) & {$[36]$} \\
\hline \multirow{11}{*}{ Protein modification } & Myosin light chain 2 & Gill (Br) & {$[36]$} \\
\hline & Calreticulin, like 2 & Gill (Br) & {$[36]$} \\
\hline & Transforming protein RhoA & Brain $(\mathrm{Br}, \mathrm{Hg})$ & {$[36,37]$} \\
\hline & Calmodulin & Brain $(\mathrm{Br})$ & {$[36]$} \\
\hline & Annexin 4 & Liver $(\mathrm{Hg})$ & {$[37]$} \\
\hline & 14-3-3E1 protein & Liver $(\mathrm{Hg})$ & {$[37]$} \\
\hline & 14-3-3 protein & Liver $(\mathrm{Hg})$ & {$[37]$} \\
\hline & Annexin A13 & Brain $(\mathrm{Hg})$ & {$[37]$} \\
\hline & Cytosolic nonspecific dipeptidase & Liver $(\mathrm{Hg})$ & {$[37]$} \\
\hline & Proteasome alpha 1 subunit & Liver $(\mathrm{Hg})$ & {$[37]$} \\
\hline & HSP-90 & Brain $(\mathrm{Hg})$ & {$[37]$} \\
\hline \multirow{11}{*}{ Other function related } & Chaperonin containing TCP1, subunit 8 (theta) & Brain $(\mathrm{Hg})$ & {$[37]$} \\
\hline & Beta-synuclein & Brain $(\mathrm{Br})$ & {$[36]$} \\
\hline & SH3-domain GRB2-like endophilin B2 & Brain $(\mathrm{Br})$ & {$[36]$} \\
\hline & Complement component C3-1 & Liver $(\mathrm{Hg})$ & {$[37]$} \\
\hline & Carbonic anhydrase 1 & Brain $(\mathrm{Hg})$ & {$[37]$} \\
\hline & ATPase, $\mathrm{H}+$ transporting, $\mathrm{V} 0$ subunit $\mathrm{D}$ isoform 1 & Brain $(\mathrm{Hg})$ & {$[37]$} \\
\hline & Transferrin & Brain $(\mathrm{Hg})$ & {$[37]$} \\
\hline & $\begin{array}{c}\text { Eukaryotic translation initiation factor 3, subunit } 2 \\
\text { beta [EIF3S2] }\end{array}$ & Liver $(\mathrm{Hg})$ & {$[38]$} \\
\hline & Histone H4 & Liver $(\mathrm{Hg})$ & {$[38]$} \\
\hline & Ependymin [EPD] & Liver $(\mathrm{Hg})$ & {$[38]$} \\
\hline & GammaN1 crystallin [CRYGN1] & Liver $(\mathrm{Hg})$ & {$[38]$} \\
\hline
\end{tabular}

Notes: the abbreviations in parentheses mean the protein expression in the environment of exposure to normal (N), hypoxia $(\mathrm{H})$, brevetoxins $(\mathrm{Br}), \mathrm{HgCl}{ }_{2}(\mathrm{Hg})$, salinity (S), $\mathrm{nZnO}(\mathrm{Z})$, and WAFs of Iranian crude oil (W).

results showed that exposure to PFOS could induce the hatching enzyme both at transcriptional and enzymatic activity levels and further lead to decreases of average hatching time and increases of the average hatchability of $O$. melastigma embryos, which in turn induced the mortality of the larvae hatched from exposed embryos. All of these effects were dose dependent [10]. They also found that PFOS is toxic to the development of the cardiovascular system of $O$. melastigma, affecting the expression of cardiac developmentrelated genes, morphological development, and function of the heart in the marine medaka [23].

Some research has also been conducted in their laboratory with embryos exposed to low concentrations of bisphenol A (BPA). The result showed that the expression of heart development-related genes and inflammation-related genes in O. melastigma was altered, the body length and width decreased, and the larvae exhibited inflammation foci in the heart ventricles [31].

4.2. Toxicological Studies for Inorganic Chemicals. Subacute toxicity experiments with ambient concentrations of pollutants are often closer to environmental value and thus have great significance in toxicological evaluation. In evaluating the toxicity of $\mathrm{ZnO}$, researchers evaluated the subacute toxicity of two zinc oxides on the expression of SOD, MT, and HSP70 in O. melastigma and found that the two zinc 


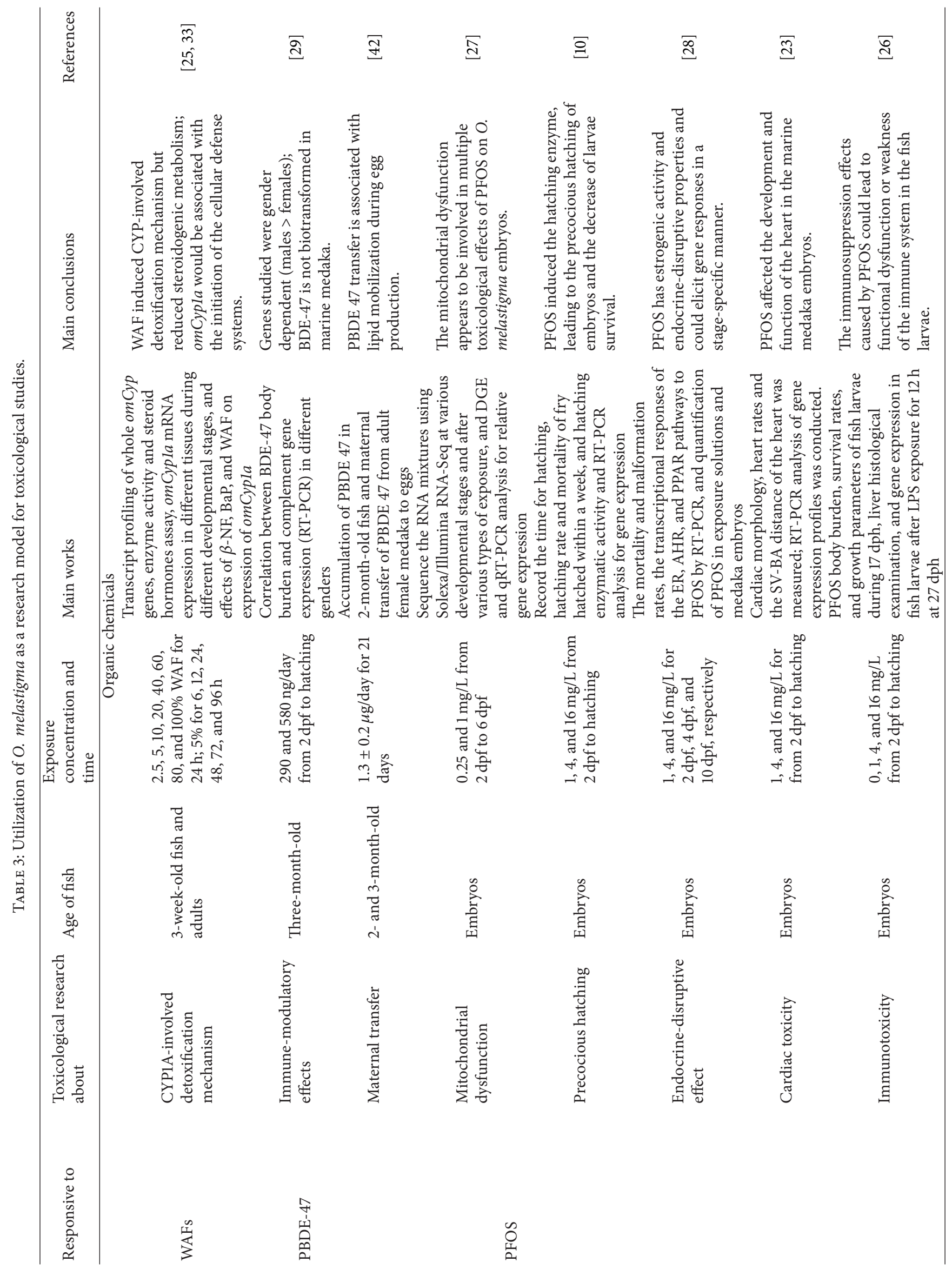




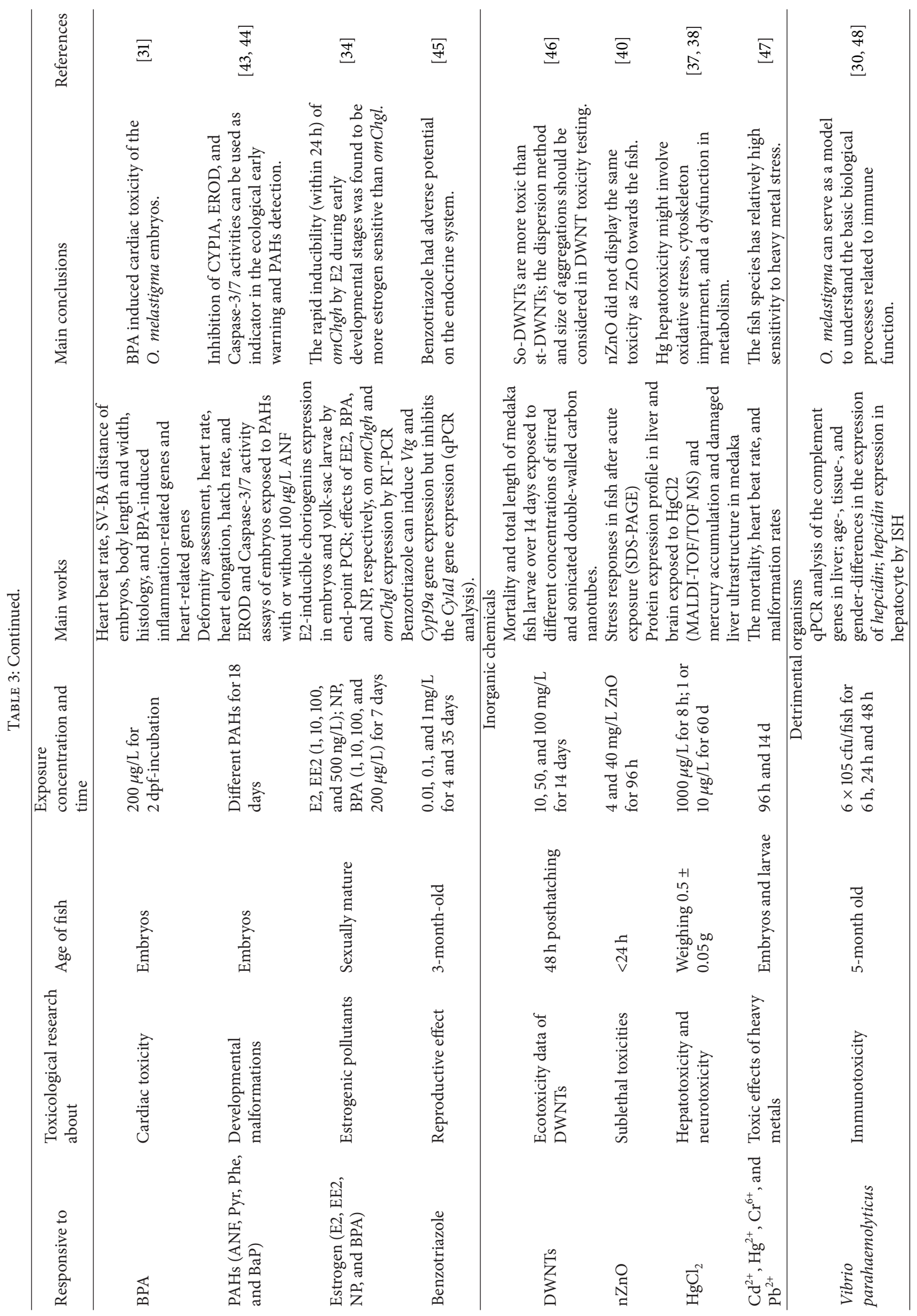




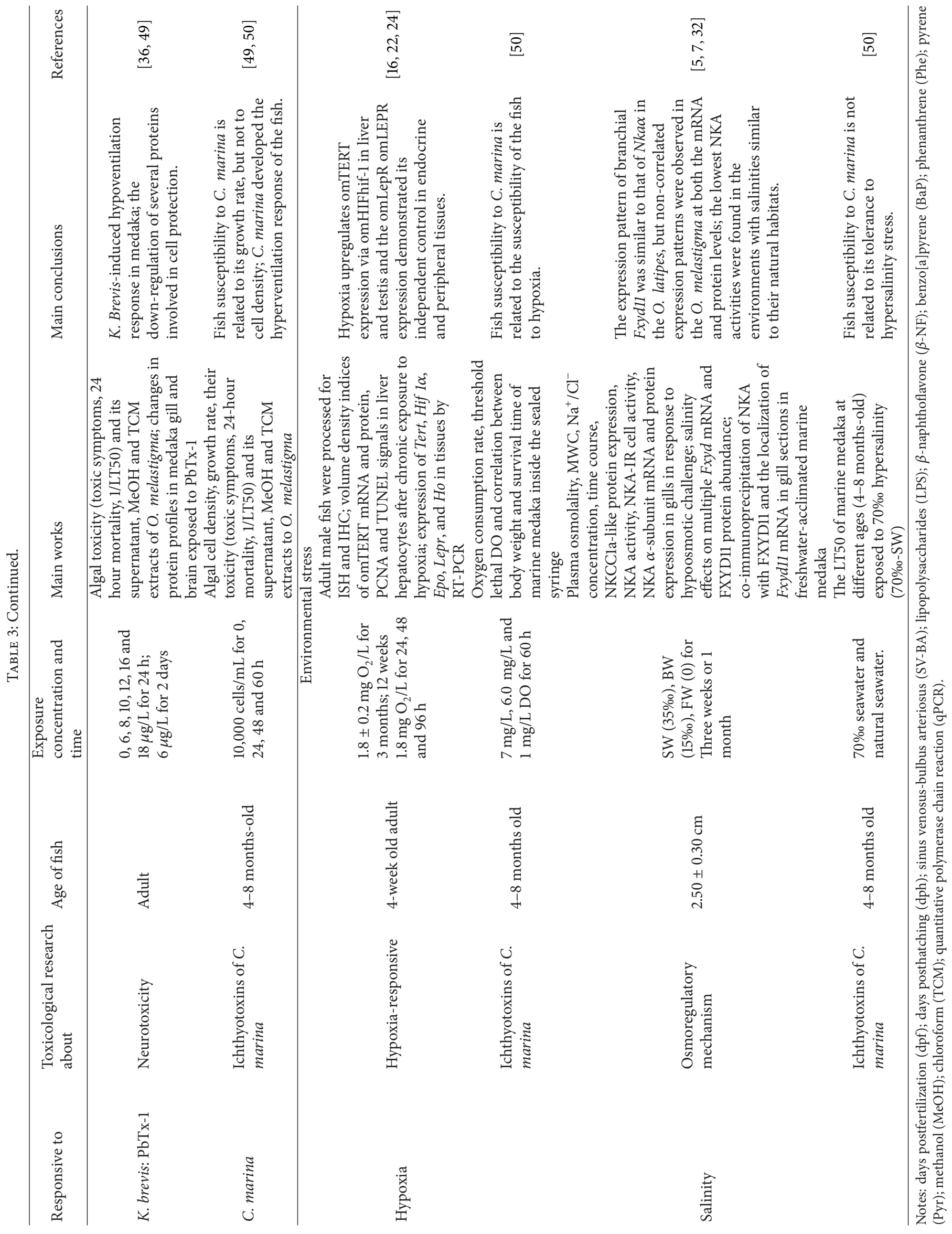


TABLE 4: Comparative toxicity of $O$. melastigma and other species under various stresses.

\begin{tabular}{|c|c|c|c|}
\hline Exposing to & O. melastigma & Other species & References \\
\hline \multirow{3}{*}{ PFOS } & $\begin{array}{l}\text { Hatched in advance and hatching rate } \\
\text { increased. }\end{array}$ & $\begin{array}{l}\text { Hatch was delayed and hatching rate was not affected or } \\
\text { decreased in zebrafish. }\end{array}$ & {$[8-10]$} \\
\hline & $\begin{array}{l}\text { Ke in the larvae ranged from } 0.04 / \mathrm{d} \text { to } \\
0.07 / \mathrm{d} \text {. }\end{array}$ & $\begin{array}{l}\text { Ke ranged from } 0.053 \text { to } 1.700 \mathrm{~L} / \mathrm{kg} / \mathrm{d} \text { in blood, kidney, } \\
\text { liver and gall bladder and from } 0.02 \text { to } 0.23 / \mathrm{d} \text { in carcass } \\
\text { and liver concentrations in rainbow trout } \\
\text { (Oncorhynchus mykiss). }\end{array}$ & [51-53] \\
\hline & Did not alter Epo & Led to high mortality in zebrafish & {$[23]$} \\
\hline Phe, Pyr, and $\mathrm{BaP}$ & $\begin{array}{l}\text { NOEC values were } 50,25 \text {, and } 10 \mu \mathrm{g} / \mathrm{L} \text {, } \\
\text { respectively. }\end{array}$ & $\begin{array}{l}\text { NOEC values were } 10,50 \text {, and } 1.8 \mu \mathrm{g} / \mathrm{L} \text {, respectively, in } \\
\text { the water flea (Tigriopus japonicus). }\end{array}$ & {$[54]$} \\
\hline $\mathrm{E} 2$ & $\begin{array}{l}\text { The mRNA level of } 3 B h s d \text { (steroidogenic } \\
\text { enzymes) was increased. }\end{array}$ & $\begin{array}{l}\text { Decreased the production of } 11-\mathrm{KT} \text { and mRNA levels of } \\
\text { steroidogenic enzymes in zebrafish and decreased the } \\
\text { production of testosterone in human }\end{array}$ & {$[55-57]$} \\
\hline DWNTs & $\begin{array}{l}\text { Growth inhibition was observed at } \\
10 \mathrm{mg} / \mathrm{L} \text { for so-DWNTs but not for } \\
\text { st-DWNTs. }\end{array}$ & $\begin{array}{l}\text { Population growth was reduced to } 0.1 \mathrm{mg} / \mathrm{L} \text { for } \\
\text { so-DWNTs and } 10 \mathrm{mg} / \mathrm{L} \text { for st-DWNTs in the water flea. }\end{array}$ & {$[23]$} \\
\hline $\mathrm{nZnO}$ & $\begin{array}{l}\text { Lack of change was observed in the SOD } \\
\text { activities. }\end{array}$ & $\begin{array}{l}\text { SOD activities were decreased for the first few days but } \\
\text { recovered soon in O. latipes and were also significantly } \\
\text { depleted in mouse embryo fibroblast cells, more toxic in } \\
\text { Skeletonema costatum and Thalassiosira pseudonana, } \\
\text { and less toxic in Elasmopus rapax and the water flea. }\end{array}$ & {$[40]$} \\
\hline Cercariae & Did not infect & $\begin{array}{l}\text { Infected in liver and kidneys of Channa punctatus, } \\
\text { infected in the muscles of Cliona orientalis, and did not } \\
\text { infect in Puntius sophore and Gambusia affinis }\end{array}$ & {$[58]$} \\
\hline \multirow[t]{2}{*}{ Salinity } & Prefers hypoosmotic conditions & $\begin{array}{l}\text { Prefers hyperosmotic conditions in Javanese medaka } \\
\text { (Oryzias Javanicus) }\end{array}$ & {$[11,59]$} \\
\hline & $\begin{array}{l}\text { MWC was constant with the increase of } \\
\text { salinity in O. melastigma. }\end{array}$ & $\begin{array}{l}\text { MWC was decreased with the increase of salinity in } O \text {. } \\
\text { latipes. }\end{array}$ & {$[7]$} \\
\hline \multirow{2}{*}{ Hypoxia } & HAS was not present. & HAS was identified in zebrafish and Fugu. & {$[60]$} \\
\hline & $\begin{array}{l}\text { 3Bhsd and Cyp19a mRNA expression } \\
\text { upregulation }\end{array}$ & $\begin{array}{l}\text { 3Bhsd and Cyp19a mRNA expression was reduced in } \\
\text { zebrafish. }\end{array}$ & {$[55]$} \\
\hline
\end{tabular}

Notes: the elimination rate constant (Ke); No Observed Effect Concentration (NOEC); 11-ketotestostrone (11-KT); HIF-1 ancillary sequence (HAS).

oxides show differences in the induction of three proteins [40]. In the toxicity assessing, double-wall carbon nanotubes (DWNTs) $(10 \mathrm{mg} / \mathrm{L})$ following ultrasonic treatment inhibited the growth of $O$. melastigma larvae [46].

O. melastigma is also used in the evaluation of heavy metal toxicity. The $96 \mathrm{~h} \mathrm{LC50s}$ of this fish following exposure to $\mathrm{Cu}^{2+}, \mathrm{Cd}^{2+}, \mathrm{Hg}^{2+}, \mathrm{Cr}^{6+}, \mathrm{Pb}^{2+}$, and $\mathrm{Zn}^{2+}$ are shown in Table 6, from which we could determine that O. melastigma has a strong sensitivity to metal stress compared to other marine species. Toxicity detection of $O$. melastigma for copper, tributyltin (TBT), and five commonly used antifouling fungicides, including s-triazine, diuron, pyrithione zinc, copper pyrithione, and chlorothalonil, indicate that the $96 \mathrm{~h}$ LC50 of this fish's tolerance for copper, s-triazine, and diuron is at the level of $\mathrm{mg} / \mathrm{L}$, while others are $\mu \mathrm{g} / \mathrm{L}$ [91]. Exposing fertilized eggs and newly hatched $O$. melastigma juveniles to $\mathrm{Cd}^{2+}, \mathrm{Hg}^{2+}, \mathrm{Cr}^{6+}$, and $\mathrm{Pb}^{2+}$ significantly reduced the hatching ability of the embryos and the heart rates above a certain concentration [47]. Metal accumulation of inorganic mercury in the liver and brain of $O$. melastigma induced oxidative stress, cytoskeletal reorganization and/or disruption, dysfunction in metabolism, protein modification, signal transduction, and other related functions $[37,38]$.
4.3. Toxicological Researches for Detrimental Organisms. The median lethal time (LT50) of O. melastigma is treated as an indicator of pollutant toxicity for toxicological comparison and correlation analysis. In addition, the acute toxicity test can provide the appropriate dose for the study of molecular toxicological mechanisms, such as the determination of the $24 \mathrm{~h}$ LC50 value in O. melastigma exposed to brevetoxins (PbTxs). These concentrations of PbTxs can be determined in follow-up proteomics studies [36].

ISH showed that Vibrio parahaemolyticus would induce the expression of hepcidin genes in the nuclei and cytoplasm of liver cells of O. melastigma [48]. It is also used to characterize the toxicity of the toxins generated by Chattonella marina and Karenia brevis. Test fishes exposed to the toxins generated by C. marina exhibit hyperventilation, while those exposed to the toxins generated by $K$. brevis exhibit hypoventilation [49]. With the assistance of the proteomic approach combined with other methods, the toxicological mechanism of aquatic toxins in marine organisms will be elucidated easily and conveniently [36].

4.4. Toxicological Studies for Environmental Stress. O. melastigma can serve as a marine fish model for assessing 
TABLE 5: Acute toxicity data (96 h LC50/EC50) of seawater organisms exposed to PAHs.

\begin{tabular}{|c|c|c|c|c|c|}
\hline \multirow{2}{*}{ Scientific name } & \multirow{2}{*}{ LC50/EC50 } & \multicolumn{3}{|c|}{ PAHs $(\mu \mathrm{g} / \mathrm{L})$} & \multirow{2}{*}{ References } \\
\hline & & Phe & Pyr & $\mathrm{BaP}$ & \\
\hline Corophium acherusicum & LC50 & 310 & 49 & - & {$[54]$} \\
\hline Neomysis awatschensis & LC50 & 130 & - & - & {$[54]$} \\
\hline Tigriopus japonicus & LC50 & 546 & 174 & 3.46 & {$[54]$} \\
\hline Neomysis awatschensis & LC50 & - & 15.2 & - & {$[54]$} \\
\hline Nitzschia closterium & EC50 & 71.5 & 56.8 & 51 & {$[54]$} \\
\hline Enteromorpha linza & EC50 & 2070 & 209 & 286 & {$[54]$} \\
\hline Oncorhynchus mykiss & LC50 & 3200 & 2000 & - & {$[64]$} \\
\hline Acanthogobius lactipes & LC50 & 295 & - & - & {$[54]$} \\
\hline Ctenogobius giurinus & LC50 & - & 13.1 & - & {$[54]$} \\
\hline O. melastigma & LC50 & 6399 & 3127 & 5705 & {$[54]$} \\
\hline Sparus macrocephalus & LC50 & 800 & - & - & {$[54]$} \\
\hline Strongylocentrotus intermedius & LC50 & 520 & - & - & {$[54]$} \\
\hline Hemicentrotus pulcherrimus & LC50 & - & 1.056 & 1.56 & {$[54]$} \\
\hline
\end{tabular}

Notes: median lethal concentration (LC50); median effective concentration (EC50).

TABLE 6: Acute toxicity data (LC50, $\mathrm{mg} / \mathrm{L})$ of metals in various species.

\begin{tabular}{|c|c|c|c|c|c|c|c|c|}
\hline \multirow{2}{*}{ Species } & \multirow{2}{*}{ Exposure ages } & \multicolumn{6}{|c|}{$\mathrm{LC} 50(\mathrm{mg} / \mathrm{L})$} & \multirow{2}{*}{ References } \\
\hline & & $\mathrm{Cu}^{2+}$ & $\mathrm{Cd}^{2+}$ & $\mathrm{Pb}^{2+}$ & $\mathrm{Cr}^{6+}$ & $\mathrm{Hg}^{2+}$ & $\mathrm{Zn}^{2+}$ & \\
\hline Argopecten ventricosus & Juvenile & - & 0.396 & 0.830 & 3.430 & - & - & {$[65]$} \\
\hline Chironomus furens & Larvae & 52.8 & 0.3 & 0.3 & 0.3 & 0.03 & 4.5 & {$[66]$} \\
\hline Chironomus plumosus & Larvae & 42.6 & 0.4 & 8.2 & 1 & 0.3 & 9.5 & {$[66]$} \\
\hline Chironomus riparius & Adult & 0.043 & 0.021 & - & - & - & - & {$[67]$} \\
\hline Cynoglossus semilaevis & Postlarvae & 0.025 & 0.178 & 1.026 & - & 0.045 & 1.18 & {$[68]$} \\
\hline Duttaphrynus melanostictus & Larvae & 0.03 & 0.3 & 4.2 & - & - & 4.2 & [69] \\
\hline Echinogammars olivii & Adult & 0.25 & - & 0.62 & - & - & 1.30 & {$[70]$} \\
\hline Farfantepenaeus paulensis & Postlarvae & - & 0.83 & - & - & - & 3.31 & {$[71]$} \\
\hline Fundulus heteroclitus & Postlarvae & 1.7 & 18.2 & 188 & - & 0.068 & 129.5 & {$[72-74]$} \\
\hline Hyalella azteca & Adult & 0.21 & 0.013 & - & - & - & - & {$[67]$} \\
\hline Hexagenia spp. & Adult & 0.073 & 7.82 & - & - & - & - & {$[67]$} \\
\hline Liza vaigiensis & Postlarvae & - & 3.7 & 138 & - & 0.0835 & - & {$[72]$} \\
\hline Lutjanus argentimaculatus & Juvenile & - & - & 98 & 20.1 & 0.38 & - & {$[75]$} \\
\hline Menidia menidia & Juvenile & - & 6.3 & - & 91 & 0.112 & - & {$[75,76]$} \\
\hline Oreochromis niloticus & Juvenile & 0.80 & - & - & - & 0.82 & - & {$[77]$} \\
\hline O. latipes & Postlarvae & - & 5.6 & - & 12.4 & - & - & {$[72]$} \\
\hline O. melastigma & Postlarvae & 7.3 & 1.12 & $>20$ & 1.456 & 0.097 & 43 & {$[78]$} \\
\hline Pagrosomus major & Postlarvae & 0.31 & 5.6 & - & - & - & 3.6 & {$[79,80]$} \\
\hline Palaemon elegans & Adult & 2.52 & - & 5.88 & - & - & 12.3 & {$[70]$} \\
\hline Penaeus indicus & Postlarvae & 0.8204 & - & 7.22 & - & - & - & {$[81,82]$} \\
\hline Penaeus monodon & Postlarvae & - & 2.28 & $5.77-7.28$ & - & - & 3.02 & {$[83,84]$} \\
\hline Penaeus penicillatus & Larvae & - & 3.025 & - & - & - & 4.267 & {$[85]$} \\
\hline Poecilia reticula & Juvenile & 2.36 & 17.71 & - & 43.4 & - & - & {$[86]$} \\
\hline Penaeus setiferus & Postlarvae & 0.0308 & - & - & - & 0.017 & - & {$[87,88]$} \\
\hline Priopidichthys marianus & Juvenile & - & - & 140 & 31 & 0.35 & - & [72] \\
\hline Rivulus marmoratus & Postlarvae & 1.4 & 21.1 & 85.3 & 14.3 & - & 147.9 & {$[72,74]$} \\
\hline Sphaeroma serratum & Adult & 1.98 & - & 4.61 & - & - & 6.12 & {$[70]$} \\
\hline Sparus macrocephalus & Larvae & 0.2 & 0.3 & - & - & - & 1.8 & {$[80]$} \\
\hline Stenocypris major & Adult & 0.0252 & 0.0131 & 0.5262 & - & - & 1.1898 & [89] \\
\hline Tubifex tubifex & Adult & 0.16 & 0.87 & - & - & - & - & {$[67]$} \\
\hline Zebrafish & Adult & 0.174 & 6.497 & 116.432 & 181.09 & 0.14 & 44.48 & {$[86,90]$} \\
\hline
\end{tabular}


molecular responses to stresses in the marine environment. Hypoxia upregulates omTert expression via omHIF-1 in the liver and testis of nonneoplastic fish [22]. Significant changes were observed in the transcription, translation, cell proliferation, and apoptosis level of TERT in the liver of $O$. melastigma exposed to hypoxic conditions for 3 months [16]. Anoxic conditions can increase the expression of Tert in the liver and testicular tissue of O. melastigma, which is mediated by anoxia-induced factor-1 [24]. The expression of leptin receptor gene exhibits tissue specificity when exposed to hypoxia, and this gene was identified as a sensitive marker gene for a hypoxic environment [22].

The experimental animal, marine medaka, is suitable for studying the mechanism of hypoosmoregulatory. Studies show that branchial omNkccla mRNA levels are induced significantly with an increase in environmental salinities. Salinity-dependent expression of Nkccla is in the branchial mitochondria-rich (MR) cells of O. melastigma, which suggests a critical role in hypoosmoregulatory endurance of this fish [32]. Studies have also indicated that O. latipes exhibited better hypoosmoregulatory ability, while $O$. melastigma exhibited better hyperosmoregulatory ability. These results support the hypothesis that the lowest branchial NKA activities of these two species were found in the environments that have similar salinities to their natural habitats [7].

\section{Conclusion}

O. melastigma have biological characteristics such as small size, high fecundity, short life cycle, sexual reproduction, and distinctive life stages that would allow their use as a marine fish model. Additionally, their ease of cultivation facilitates the use of $O$. melastigma in independent laboratories. The availability of knowledge on their sensitivity towards inorganic and organic compounds and the increasingly complete knowledge on their genes and proteins will also enhance the potential of $O$. melastigma as suitable models in marine aquatic ecotoxicology and toxicogenomics. Researchers have demonstrated the potential application of O. melastigma as an ideal marine test fish for marine pollution assessments and ecotoxicological studies of organic chemicals, inorganic chemicals, microorganism, and environmental stress in relation to cardiac toxicity, hepatotoxicity, neurotoxicity, ecotoxicity, immunotoxicity, and so forth.

O. melastigma can also serve as a model marine fish for assessing multiple in vivo molecular responses to stresses in the marine environment. O. melastigma showed high tolerance to PAHs and strong sensitivity to metal stress compared to other species. The heart elongation of O. melastigma embryo and omChgh and omLepr expression are used as potential biomarkers to indicate PAH mixtures contamination or an oil spill, estrogenic chemicals in the marine environment, and growth and/or endocrine disruption in this marine fish, respectively. The expression of the leptin receptor gene, which was identified as a sensitive marker gene for hypoxia environment, exhibits tissue specificity in O. melastigma. We may be able to develop biomarkers for more specific adverse effects that can be used for both ecotoxicology and human health risk assessment because of the high degree of evolutionary conservation among vertebrates [92].

Although some toxicological research has been conducted using this small fish species as a model, there is still much to be studied. Fortunately, transcriptome analyses and proteomic approaches, along with new methodologies in $O$. melastigma, such as gene knockdown, gene overexpression, gene chip technology, second-generation high-throughput sequencing technology, RNA-Seq, and DGE technology, can be expected to further accelerate the knowledge of the toxicological mechanisms of aquatic toxins in marine animals in the future. Demonstrating and understanding toxicity mechanisms in O. melastigma that are common between humans and fish and wildlife are necessary if we are to integrate findings from laboratory and ecotoxicology studies with human health risk assessment.

\section{Conflict of Interests}

The authors declare that there is no conflict of interests regarding the publication of this paper.

\section{Acknowledgments}

This work was supported by the National Natural Science Foundation of China $(21207127,21277137)$. The authors thank Qiansheng Huang and Kevin Francesconi for critical discussion and correction of the manuscript.

\section{References}

[1] X. Chen, L. Li, C. K. C. Wong, and S. H. Cheng, "Rapid adaptation of molecular resources from zebrafish and medaka to develop an estuarine/marine model," Comparative Biochemistry and Physiology C, vol. 149, no. 4, pp. 647-655, 2009.

[2] R. A. French, A. R. Jacobson, B. Kim, S. L. Isley, L. Penn, and P. C. Baveye, "Influence of ionic strength, $\mathrm{pH}$, and cation valence on aggregation kinetics of titanium dioxide nanoparticles," Environmental Science and Technology, vol. 43, no. 5, pp. 13541359, 2009.

[3] C. You, C. Jia, and G. Pan, "Effect of salinity and sediment characteristics on the sorption and desorption of perfluorooctane sulfonate at sediment-water interface," Environmental Pollution, vol. 158, no. 5, pp. 1343-1347, 2010.

[4] J. Jeon, K. Kannan, H. K. Lim, H. B. Moon, J. S. Ra, and S. D. Kim, "Bioaccumulation of perfluorochemicals in pacific oyster under different salinity gradients," Environmental Science and Technology, vol. 44, no. 7, pp. 2695-2701, 2010.

[5] W. K. Yang, C. K. Kang, C. H. Chang, A. D. Hsu, T. H. Lee, and P. P. Hwang, "Expression profiles of branchial FXYD proteins in the brackish medaka Oryzias dancena: a potential saltwater fish model for studies of osmoregulation," PLOS ONE, vol. 8, no. 1, Article ID e55470, 2013.

[6] N. Y. Ho, V. W. T. Li, W. L. Poon, and S. H. Cheng, "Cloning and developmental expression of kinesin superfamily7 (kif7) in the brackish medaka (Oryzias melastigma), a close relative of the Japanese medaka (Oryzias latipes)," Marine Pollution Bulletin, vol. 57, no. 6-12, pp. 425-432, 2008.

[7] C.-K. Kang, S.-C. Tsai, T.-H. Lee, and P.-P. Hwang, "Differential expression of branchial $\mathrm{Na}+/ \mathrm{K}+$-ATPase of two medaka species, 
Oryzias latipes and Oryzias dancena, with different salinity tolerances acclimated to fresh water, brackish water and seawater," Comparative Biochemistry and Physiology A, vol. 151, no. 4, pp. 566-575, 2008.

[8] X. Shi, Y. Du, P. K. S. Lam, R. S. S. Wu, and B. Zhou, "Developmental toxicity and alteration of gene expression in zebrafish embryos exposed to PFOS," Toxicology and Applied Pharmacology, vol. 230, no. 1, pp. 23-32, 2008.

[9] A. Hagenaars, L. Vergauwen, W. De Coen, and D. Knapen, "Structure-activity relationship assessment of four perfluorinated chemicals using a prolonged zebrafish early life stage test," Chemosphere, vol. 82, no. 5, pp. 764-772, 2011.

[10] X. Wu, Q. Huang, C. Fang, T. Ye, L. Qiu, and S. Dong, "PFOS induced precocious hatching of Oryzias melastigmafrom molecular level to individual level," Chemosphere, vol. 87, no. 7, pp. 703-708, 2012.

[11] K. Inoue and Y. Takei, "Diverse adaptability in Oryzias species to high environmental salinity," Zoological Science, vol. 19, no. 7, pp. 727-734, 2002.

[12] W. P. Yip, Relating Estradiol and Telomeres to Longevity in Marine Medaka Oryzias melastigma, City University of Hong Kong, 2011.

[13] D. W. T. Au, "15th international symposium ontoxicity assessment," Environmental Science and Pollution Research, vol. 19, pp. 2463-2464, 2012.

[14] M. Kinoshita, K. Murata, K. Naruse, and M. Tanaka, Medaka: Biology, Management, and Experimental Protocols, WileyBlackwell, 2009.

[15] X. Chen, L. Li, J. Cheng et al., "Molecular staging of marine medaka: a model organism for marine ecotoxicity study," Marine Pollution Bulletin, vol. 63, no. 5-12, pp. 309-317, 2011.

[16] R. Y. C. Kong, J. P. Giesy, R. S. S. Wu et al., "Development of a marine fish model for studying in vivo molecular responses in ecotoxicology," Aquatic Toxicology, vol. 86, no. 2, pp. 131-141, 2008.

[17] D. E. Hinton, R. C. Hardman, S. W. Kullman et al., "Aquatic animal models of human disease: selected papers and recommendations from the 4th Conference," Comparative Biochemistry and Physiology C, vol. 149, no. 2, pp. 121-128, 2009.

[18] C. Lee, S. H. Jeon, J. G. Na, and K. Park, "Sequence analysis of choriogenin $\mathrm{H}$ gene of medaka (Oryzias latipes) and mRNA expression," Environmental Toxicology and Chemistry, vol. 21, no. 8, pp. 1709-1714, 2002.

[19] A. Kanamori, K. Naruse, H. Mitani, A. Shima, and H. Hori, "Genomic organization of ZP domain containing egg envelope genes in medaka (Oryzias latipes)," Gene, vol. 305, no. 1, pp. 3545, 2003.

[20] S. Y. Lee, D. S. Kim, and Y. K. Nam, "Gene structure and estrogenresponsive mRNA expression of a novel choriogenin $\mathrm{H}$ isoform from a marine medaka (Oryzias dancena)," Fisheries \& Aquatic Sciences, vol. 15, 2012.

[21] D. S. Hwang, B. M. Kim, D. W. T. Au, and J. S. Lee, "Complete mitochondrial genome of the marine medaka Oryzias melastigma (Beloniformes, Adrianichthyidae)," Mitochondrial DNA, vol. 23, no. 4, pp. 308-309, 2012.

[22] R. M. K. Yu, E. X. H. Chen, R. Y. C. Kong, P. K. S. Ng, H. O. L. Mok, and D. W. T. Au, "Hypoxia induces telomerase reverse transcriptase (TERT) gene expression in non-tumor fish tissues in vivo: the marine medaka (Oryzias melastigma) model," BMC Molecular Biology, vol. 7, article no. 27, 2006.
[23] Q. Huang, C. Fang, X. Wu, J. Fan, and S. Dong, "Perfluorooctane sulfonate impairs the cardiac development of a marine medaka (Oryzias melastigma)," Aquatic Toxicology, vol. 105, no. 1-2, pp. 71-77, 2011.

[24] M. M. L. Wong, R. M. K. Yu, P. K. S. Ng, S. H. W. Law, A. K. C. Tsang, and R. Y. C. Kong, "Characterization of a hypoxiaresponsive leptin receptor (omLepRL) cDNA from the marine medaka (Oryzias melastigma)," Marine Pollution Bulletin, vol. 54, no. 6, pp. 797-803, 2007.

[25] J. S. Rhee, B. M. Kim, B. S. Choi et al., "Whole spectrum of cytochrome P450 genes and molecular responses to wateraccommodated fractions exposure in the marine Medaka," Environmental Science \& Technology, vol. 47, no. 9, pp. 48044812, 2013.

[26] C. Fang, Q. Huang, T. Ye et al., "Embryonic exposure to PFOS induces immunosuppression in the fish larvae of marine Medaka," Ecotoxicology and Environmental Safety, vol. 92, pp. 104-111, 2013.

[27] Q. Huang, S. Dong, C. Fang, X. Wu, T. Ye, and Y. Lin, "Deep sequencing-based transcriptome profiling analysis of Oryzias melastigma exposed to PFOS," Aquatic Toxicology, vol. 120, pp. 54-58, 2012.

[28] C. Fang, X. Wu, Q. Huang et al., "PFOS elicits transcriptional responses of the ER, AHR and PPAR pathways in Oryzias melastigma in a stage-specific manner," Aquatic Toxicology, vol. 106-107, pp. 9-19, 2012.

[29] R. R. Ye, E. N. Y. Lei, M. H. W. Lam et al., "Gender-specific modulation of immune system complement gene expression in marine medaka Oryzias melastigma following dietary exposure of BDE-47," Environmental Science and Pollution Research, vol. 19, no. 7, pp. 2477-2487, 2011.

[30] J. Bo, J. P. Giesy, R. Ye, K.-J. Wang, J.-S. Lee, and D. W. T. Au, "Identification of differentially expressed genes and quantitative expression of complement genes in the liver of marine medaka Oryzias melastigma challenged with Vibrio parahaemolyticus," Comparative Biochemistry and Physiology D, vol. 7, no. 2, pp. 191-200, 2012.

[31] Q. Huang, C. Fang, Y. Chen et al., "Embryonic exposure to low concentration of bisphenol A affects the development of Oryzias melastigma larvae," Environmental Science and Pollution Research, vol. 19, pp. 2506-2514, 2012.

[32] C.-K. Kang, H.-J. Tsai, C.-C. Liu, T.-H. Lee, and P.-P. Hwang, "Salinity-dependent expression of a $\mathrm{Na}+, \mathrm{K}+, 2 \mathrm{Cl}$ - cotransporter in gills of the brackish medaka Oryzias dancena: a molecular correlate for hyposmoregulatory endurance," Comparative Biochemistry and Physiology A, vol. 157, no. 1, pp. 7-18, 2010.

[33] R. O. Kim, B. M. Kim, D. S. Hwang et al., "Evaluation of biomarker potential of cytochrome P450 1A (CYP1A) gene in the marine medaka, Oryzias melastigma exposed to wateraccommodated fractions (WAFs) of Iranian crude oil," Comparative Biochemistry and Physiology C, vol. 157, pp. 172-182, 2013.

[34] X. Chen, V. W. T. Li, R. M. K. Yu, and S. H. Cheng, "Choriogenin mRNA as a sensitive molecular biomarker for estrogenic chemicals in developing brackish medaka (Oryzias melastigma)," Ecotoxicology and Environmental Safety, vol. 71, no. 1, pp. 200208, 2008.

[35] C. Yao, F. zhijun, Z. Jinshu et al., "Design of marine medaka (Oryzias melastigma) functional specific cDNA microarray and its ecotoxicological application," Journal of Oceanography in Taiwan Strait, vol. 29, no. 3, pp. 359-366.

[36] L. Tian, M. Wang, X. Li et al., "Proteomic modification in gills and brains of medaka fish (Oryzias melastigma) after 
exposure to a sodium channel activator neurotoxin, brevetoxin1," Aquatic Toxicology, vol. 104, no. 3-4, pp. 211-217, 2011.

[37] M. Wang, Y. Wang, J. Wang, L. Lin, H. Hong, and D. Wang, "Proteome profiles in medaka (Oryzias melastigma) liver and brain experimentally exposed to acute inorganic mercury," Aquatic Toxicology, vol. 103, no. 3-4, pp. 129-139, 2011.

[38] M. Wang, Y. Wang, L. Zhang, J. Wang, H. Hong, and D. Wang, "Quantitative proteomic analysis reveals the mode-of-action for chronic mercury hepatotoxicity to marine medaka (Oryzias melastigma)," Aquatic Toxicology, vol. 130, pp. 123-131, 2013.

[39] H.-Q. Gu and Q.-Q. Chen, "Persistent toxic substances in offshore zone of China: a review," Acta Ecologica Sinica, vol. 28, no. 12, pp. 6243-6251, 2008.

[40] S. W. Wong, P. T. Leung, A. Djurišić, and K. M. Y. Leung, “Toxicities of nano zinc oxide to five marine organisms: influences of aggregate size and ion solubility," Analytical and Bioanalytical Chemistry, vol. 396, no. 2, pp. 609-618, 2010.

[41] T. Taguchi, A. Seko, K. Kitajima et al., "Structural studies of a novel type of tetraantennary sialoglycan unit in a carbohydraterich glycopeptide isolated from the fertilized eggs of Indian Medaka fish, Oryzias melastigma," The Journal of Biological Chemistry, vol. 268, no. 4, pp. 2353-2362, 1993.

[42] J. P. van de Merwe, A. K. Y. Chan, E. N. Y. Lei, M. S. Yau, M. H. W. Lam, and R. S. S. Wu, "Bioaccumulation and maternal transfer of PBDE 47 in the marine medaka (Oryzias melastigma) following dietary exposure," Aquatic Toxicology, vol. 103, no. 34, pp. 199-204, 2011.

[43] J. Mu, X. Wang, F. Jin, J. Wang, and H. Hong, "The role of cytochrome P4501A activity inhibition in three-to five-ringed polycyclic aromatic hydrocarbons embryotoxicity of marine medaka (Oryzias melastigma)," Marine Pollution Bulletin, vol. 64, pp. 1445-1451, 2012.

[44] L. Xiao-long, W. Xin-hong, Z. Yan-yan, H. Hua-sheng, M. Jing-li, and F. Chao, "Quantification of PAHs pollution in marine environment by measurements of EROD activity and Caspase-3/7 activity in marine madaka (Oryzias melastigma) embryos," in Proceedings of the 5th International Conference on Bioinformatics and Biomedical Engineering (iCBBE '11), chn, May 2011.

[45] H. Tangtian, L. Bo, L. Wenhua, P. K. S. Shin, and R. S. S. $\mathrm{Wu}$, "Estrogenic potential of benzotriazole on marine medaka (Oryzias melastigma)," Ecotoxicology and Environmental Safety, vol. 80, pp. 327-332, 2012.

[46] K. W. Kwok, K. M. Leung, E. Flahaut, J. Cheng, and S. H. Cheng, "Chronic toxicity of double-walled carbon nanotubes to three marine organisms: influence of different dispersion methods," Nanomedicine, vol. 5, no. 6, pp. 951-961, 2010.

[47] J. Mu, Y. Wang, X. Wang, and J. Wang, "Toxic effects of cadmium, mercury, chromium and lead on the early life stage of marine Medaka (Oryzias melastigma)," Asian Journal of Ecotoxicology, vol. 6, no. 4, pp. 352-360, 2011.

[48] J. Bo, L. Cai, J.-H. Xu, K.-J. Wang, and D. W. T. Au, “The marine medaka Oryzias melastigma-a potential marine fish model for innate immune study," Marine Pollution Bulletin, vol. 63, no. 512, pp. 267-276, 2011.

[49] M. Shen, J. Xu, T. Y. Tsang, and D. W. T. Au, “Toxicity comparison between Chattonella marina and Karenia brevis using marine medaka (Oryzias melastigma): evidence against the suspected ichthyotoxins of Chattonella marina," Chemosphere, vol. 80, no. 5, pp. 585-591, 2010.

[50] M. Shen, J. Xu, A. K. Y. Chan, and D. W. T. Au, "Susceptibility of fish to Chattonella marina is determined by its tolerance to hypoxia," Marine Pollution Bulletin, vol. 63, no. 5-12, pp. 189194, 2011.

[51] J. W. Martin, S. A. Mabury, K. R. Solomon, and D. C. G. Muir, "Bioconcentration and tissue distribution of perfluorinated acids in rainbow trout (Oncorhynchus mykiss)," Environmental Toxicology and Chemistry, vol. 22, no. 1, pp. 196-204, 2003.

[52] J. W. Martin, S. A. Mabury, K. R. Solomon, and D. C. G. Muir, "Dietary accumulation of perfluorinated acids in juvenile rainbow trout (Oncorhynchus mykiss)," Environmental Toxicology and Chemistry, vol. 22, no. 1, pp. 189-195, 2003.

[53] G. T. Ankley, D. W. Kuehl, M. D. Kahl, K. M. Jensen, B. C. Butterworth, and J. W. Nichols, "Partial life-cycle toxicity and bioconcentration modeling of perfluorooctanesulfonate in the northern leopard frog (Rana pipiens)," Environmental Toxicology and Chemistry, vol. 23, no. 11, pp. 2745-2755, 2004.

[54] Y. Wang, J. Wang, J. Mu, Z. Wang, Z. Yao, and Z. Lin, “Aquatic predicted no-effect concentration for three polycyclic aromatic hydrocarbons and probabilistic ecological risk assessment in Liaodong Bay of the Bohai Sea, China," Environmental Science and Pollution Research, vol. 21, no. 1, pp. 148-158, 2014.

[55] A. C. Tse, K. Y. Lau, W. Ge, and R. S. Wu, "A rapid screening test for endocrine disrupting chemicals using primary cell culture of the marine medaka," Aquatic Toxicology, vol. 144-145, pp. 50-58, 2013.

[56] T. M. Jones, V. S. Fang, R. L. Landau, and R. Rosenfield, "Direct inhibition of Leydig cell function by estradiol," Journal of Clinical Endocrinology and Metabolism, vol. 47, no. 6, pp. 1368-1373, 1978.

[57] P. P. de Waal, M. C. Leal, Á. García-López et al., “Oestrogeninduced androgen insufficiency results in a reduction of proliferation and differentiation of spermatogonia in the zebrafish testis," Journal of Endocrinology, vol. 202, no. 2, pp. 287-297, 2009.

[58] K. Jhansilakshmibai and R. Madhavi, "Euclinostomum heterostomum (Rudolphi, 1809) (Trematoda): life-cycle, growth and development of the metacercaria and adult," Systematic Parasitology, vol. 38, no. 1, pp. 51-64, 1997.

[59] S. Yusof, A. Ismail, T. Koito, M. Kinoshita, and K. Inoue, "Occurrence of two closely related ricefishes, Javanese medaka (Oryzias javanicus) and Indian medaka (O. dancena) at sites with different salinity in Peninsular Malaysia," Environmental Biology of Fishes, vol. 93, no. 1, pp. 43-49, 2012.

[60] R. M. K. Yu, E. X. H. Chen, R. Y. C. Kong, P. K. S. Ng, H. O. L. Mok, and D. W. T. Au, "Hypoxia induces telomerase reverse transcriptase (TERT) gene expression in non-tumor fish tissues in vivo: the marine medaka (Oryzias melastigma) model," BMC Molecular Biology, vol. 7, article 27, 2006.

[61] C. Liu, Y. Du, and B. Zhou, "Evaluation of estrogenic activities and mechanism of action of perfluorinated chemicals determined by vitellogenin induction in primary cultured tilapia hepatocytes," Aquatic Toxicology, vol. 85, no. 4, pp. 267-277, 2007.

[62] Y. Du, X. Shi, C. Liu, K. Yu, and B. Zhou, "Chronic effects of water-borne PFOS exposure on growth, survival and hepatotoxicity in zebrafish: a partial life-cycle test," Chemosphere, vol. 74, no. 5, pp. 723-729, 2009.

[63] M. E. Austin, B. S. Kasturi, M. Barber, K. Kannan, P. S. MohanKumar, and S. M. J. MohanKumar, "Neuroendocrine effects of perflurooactane sulfonate in rats," Environmental Health Perspectives, vol. 111, no. 12, pp. 1485-1489, 2003.

[64] C. C. Edsall, "Acute toxicities to larval rainbow trout of representative compounds detected in great lakes fish," Bulletin of 
Environmental Contamination and Toxicology, vol. 46, no. 2, pp. 173-178, 1991.

[65] A. S. Sobrino-Figueroa, C. Cáceres-Martínez, A. V. Botello, and G. Nunez-Nogueira, "Effect of cadmium, chromium, lead and metal mixtures on survival and growth of juveniles of the scallop Argopecten ventricosus (Sowerby II, 1842)," Journal of Environmental Science and Health A, vol. 42, no. 10, pp. 14431447, 2007.

[66] V. J. Vedamanikam and N. A. M. Shazilli, "The effect of multigenerational exposure to metals and resultant change in median lethal toxicity tests values over subsequent generations," Bulletin of Environmental Contamination and Toxicology, vol. 80, no. 1, pp. 63-67, 2008.

[67] D. Milani, T. B. Reynoldson, U. Borgmann, and J. Kolasa, "The relative sensitivity of four benthic invertebrates to metals in spiked-sediment exposures and application to contaminated field sediment," Environmental Toxicology and Chemistry, vol. 22, no. 4, pp. 845-854, 2003.

[68] X. Liu, Y. Xu, and G. Lan, "Toxic effects of several heavy metals on the embryos, larvae of Cynoglossus semilaevis Gunther," Marine Fisheries Research, vol. 27, no. 2, pp. 33-42, 2006.

[69] M. Shuhaimi-Othman, Y. Nadzifah, N. Umirah, and A. Ahmad, "Toxicity of metals to tadpoles of the common Sunda toad, Duttaphrynus melanostictus," Toxicological \& Environmental Chemistry, vol. 94, no. 2, pp. 364-376, 2012.

[70] L. Bat, A. Gündogdu, M. Sezgin, M. Çulha, and G. Cönlugür, "Acute toxicity of zinc, copper and lead to three species of marine organisms from the Sinop Peninsula, Black Sea," Turkish Journal of Biology, vol. 23, pp. 537-544, 1999.

[71] E. Barbieri, "Effects of zinc and cadmium on oxygen consumption and ammonium excretion in pink shrimp (Farfantepenaeus paulensis, Pérez-Farfante, 1967, Crustacea)," Ecotoxicology, vol. 18, no. 3, pp. 312-318, 2009.

[72] N. Sulaiman and W. Noor, "Aquatic toxicity testing of copper, cadmium, and ammonia on seabass, lates calcarifer. in asean marine environmental management quality criteria and monitoring for aquatic life and human health protection," in Proceeding of the ASEAN-Canada Technical Conference on Marine Science, Penang, Malaysia, 1997.

[73] E. Jackim, J. M. Hamlin, and S. Sonis, "Effects of metal poisoning on five liver enzymes in the killifish (Fundulus heteroclitus)," Journal of the Fisheries Board of Canada, vol. 27, no. 2, pp. 383390, 1970.

[74] H.-C. Lin and W. A. Dunson, "The effect of salinity on the acute toxicity of cadmium to the tropical, estuarine, hermaphroditic fish, Rivulus marmoratus: a comparison of $\mathrm{Cd}, \mathrm{Cu}$, and $\mathrm{Zn}$ tolerance with Fundulus heteroclitus," Archives of Environmental Contamination and Toxicology, vol. 25, no. 1, pp. 41-47, 1993.

[75] G. Denton and C. Burdon-Jones, "Environmental effects on toxicity of heavy metals to two species of tropical marine fish from Northern Australia," Chemistry and Ecology, vol. 2, no. 3, pp. 233-249, 1986.

[76] R. Chumnantana, J. Sanguansin, and J. Koyama, "Study on acute toxicity test of cadmium to red snapper juvenile, Lutjanus argentimaculatus (Forskal)," Thai Marine Fisheries Research Bulletin, vol. 3, pp. 55-59, 1992.

[77] K. M. El-Moselhy, L. I. Mohamedein, and M. A. Abdelmoneim, "Acute Toxicity of copper and mercury to different life stages of the Nile Tilapia (Oreochromis niloticus)," African J. Biol. Sci., vol. 7, no. 2, pp. 13-21, 2011.

[78] J. L. Mu, Y. Wang, and X. H. Wang, "Toxic effects of cadmium, mercury, chromium and lead on the early life stage of marine medaka (Oryzias melastigma)," Asian Journal of Ecotoxicology, vol. 6, no. 4, pp. 352-360, 2011.

[79] L. Cao, W. Huang, X. Shan, Z. Xiao, Q. Wang, and S. Dou, "Cadmium toxicity to embryonic-larval development and survival in red sea bream Pagrus major," Ecotoxicology and Environmental Safety, vol. 72, no. 7, pp. 1966-1974, 2009.

[80] Y. Bo, Z. Weiyun, C. Mingda, Z. Zhixia, and S. Yongquan, "The toxicities of $\mathrm{Cu}, \mathrm{Zn}, \mathrm{Cd}$ on larval red sea bream and larval black sea bream," Journal of Xiamen University: Natural Science, vol. 33, supplement 1, pp. 28-30, 1994 (Chinese).

[81] R. V. Paila and P. R. Yallapragada, "Bioaccumulation and toxic effects of copper on growth and oxygen consumption by the postlarvae of Penaeus indicus," Chemistry and Ecology, vol. 26, no. 3, pp. 209-221, 2010.

[82] S. Chinni, R. N. Khan, and P. R. Yallapragada, "Acute toxicity of lead on tolerance, oxygen consumption, ammonia-N excretion, and metal accumulation in Penaeus indicus postlarvae," Ecotoxicology and Environmental Safety, vol. 51, no. 2, pp. 79-84, 2002.

[83] G. Hariharan, C. Suresh Kumar, S. Laxmi Priya et al., "Acute and chronic toxic effect of lead $(\mathrm{Pb})$ and zinc $(\mathrm{Zn})$ on biomarker response in post larvae of Penaeus monodon (Fabricus, 1798)," Toxicological \& Environmental Chemistry, vol. 94, no. 8, pp. 1571-1582, 2012.

[84] O. Fafioye and B. Ogunsanwo, "The comparative toxicities of cadmium, copper and lead to Macrobrachium rosenbergii and Penaeus monodon postlarvae," African Journal of Agricultural Research, vol. 2, no. 1, pp. 31-35, 2007.

[85] S. Gao and D. Zou, "Acute toxicity of Cd, Zn and Mn to larvae of Penaeus penicillatus," Marine Science Bulletin, vol. 14, no. 6, pp. 83-86, 1995.

[86] Z. Yan, Toxic Effect of Several Heavy Metals on Guppy, Shandong National University, 2010.

[87] E. Garnacho, L. S. Peck, and P. A. Tyler, "Variations between winter and summer in the toxicity of copper to a population of the mysid Praunus flexuosus," Marine Biology, vol. 137, no. 4, pp. 631-636, 2000.

[88] F. A. Green Jr., J. W. Anderson, and S. R. Petrocelli, "Effect of mercury on the survival, respiration, and growth of postlarval white shrimp, Penaeus setiferus," Marine Biology, vol. 37, no. 1, pp. 75-81, 1976.

[89] M. Shuhaimi-Othman, N. Yakub, N.-A. Ramle, and A. Abas, "Toxicity of metals to a freshwater ostracod: stenocypris major," Journal of Toxicology, vol. 2011, Article ID 136104, 2011.

[90] W. Hongjun, L. Sixin, Z. Lianfeng, Z. Jinxiu, and L. Youguang, "The effect of exposure to five kinds of heavy metals on respiratory movement of Zebra Fish (Brachydanio rerio)," Journal of Agro-Environment Science, vol. 29, no. 9, pp. 1675-1680, 2010.

[91] V. W. W. Bao, K. M. Y. Leung, J.-W. Qiu, and M. H. W. Lam, "Acute toxicities of five commonly used antifouling booster biocides to selected subtropical and cosmopolitan marine species," Marine Pollution Bulletin, vol. 62, no. 5, pp. 1147-1151, 2011.

[92] T. C. King-Heiden, V. Mehta, K. M. Xiong et al., "Reproductive and developmental toxicity of dioxin in fish," Molecular and Cellular Endocrinology, vol. 354, no. 1-2, pp. 121-138, 2012. 

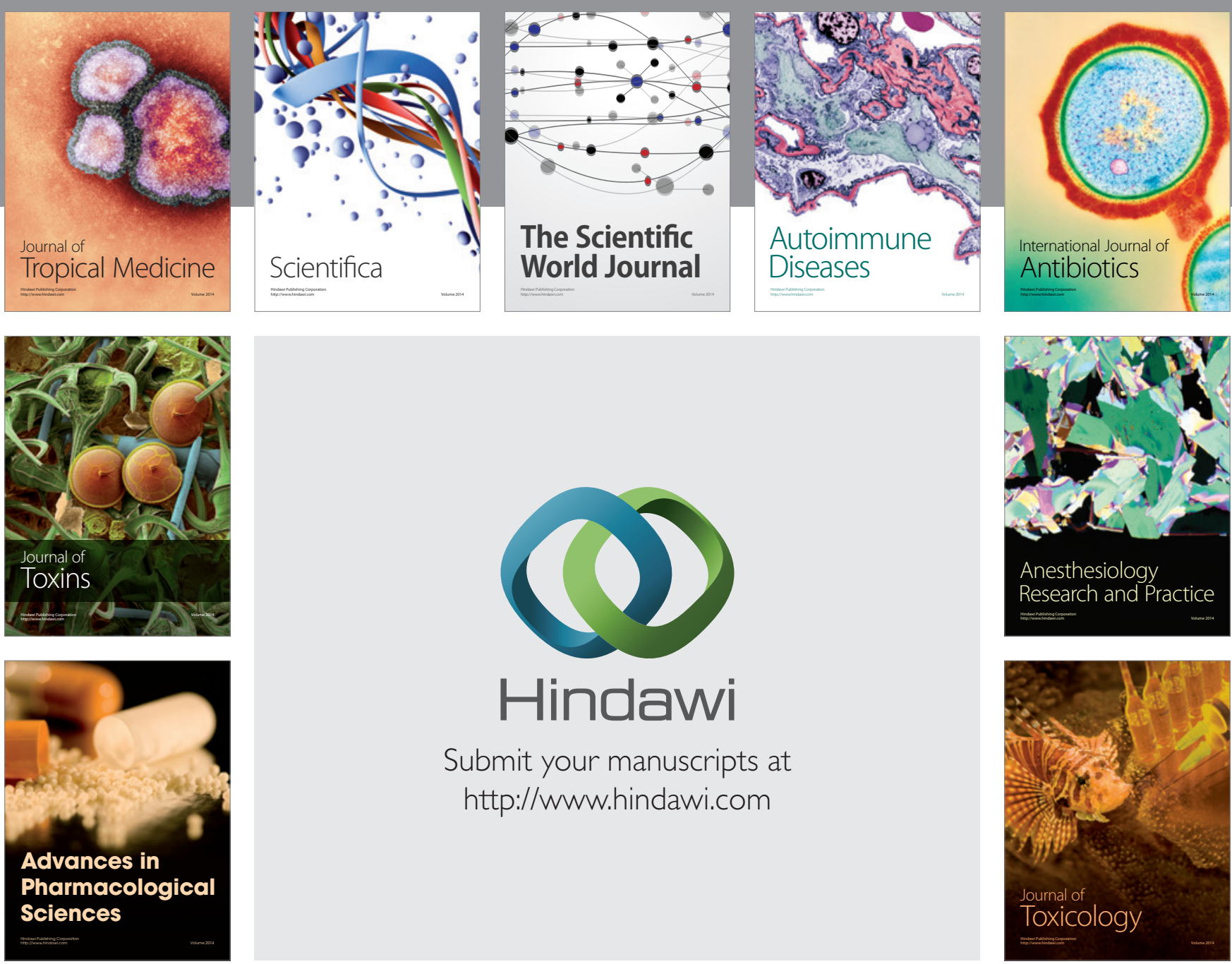

\section{Hindawi}

Submit your manuscripts at

http://www.hindawi.com
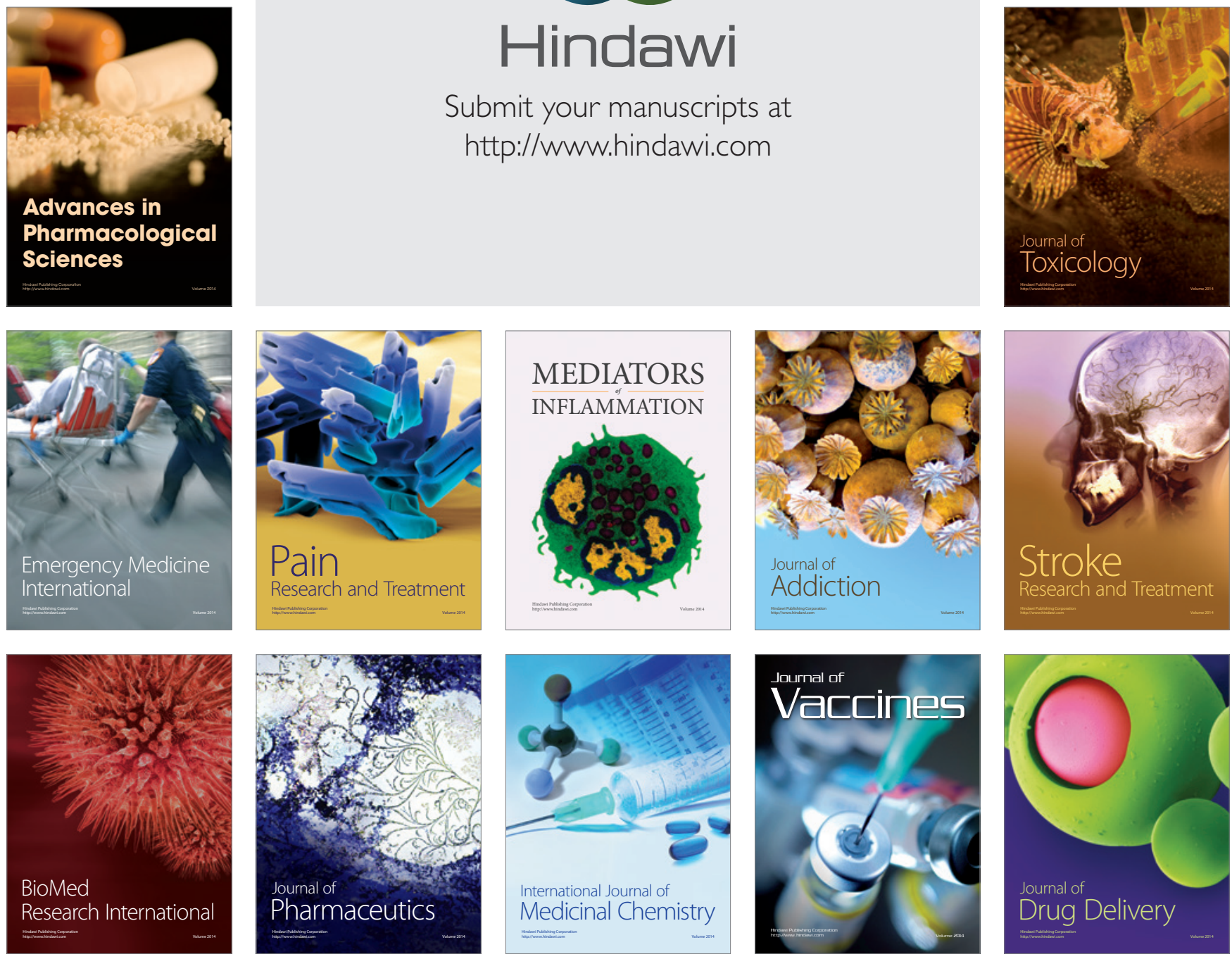